\title{
SôBRE A BIOLOGIA DA CORVINA DA COSTA SUL DO BRASIL
}

(Recebido em 3/6/61)

\author{
G. Vazzoler *
}

CONTEÛDO

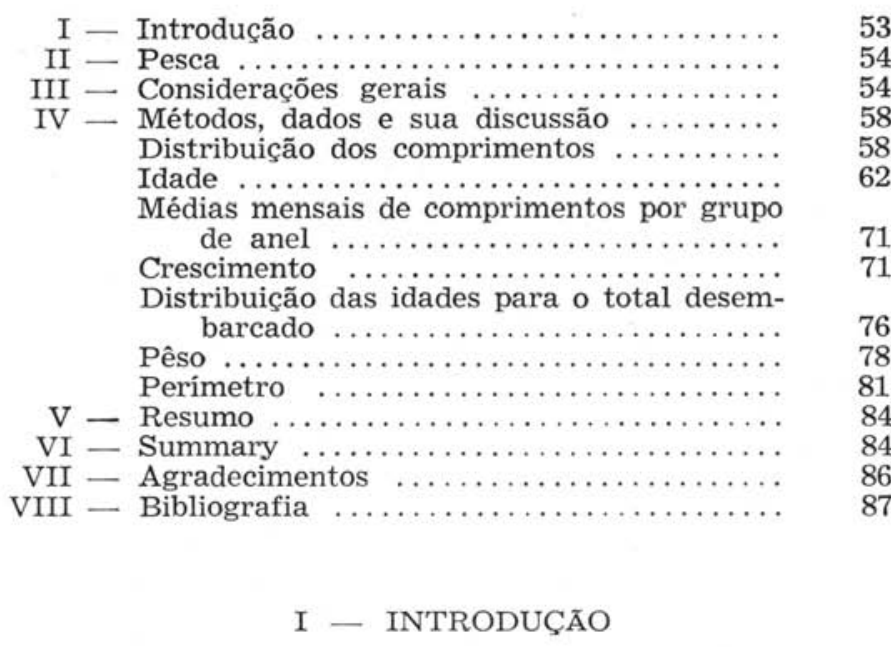

A finalidade dêste trabalho sôbre a corvina - Micropogon furnieri (=M. opercularis) (Desmarest, 1822) Jordan, 1884 - é mostrar os primeiros resultados obtidos sôbre a distribuição das freqüências de comprimentos, determinação da idade e crescimento (idade-comprimento, idade-pêso e idade-perímetro) e relações comprimento-pêso, comprimento-perímetro e pêso-perímetro.

* Instituto Oceanográfico da Universidade de São Paulo. Membro do Grupo de Pesquisas sôbre a Pesca Maritima (G.P.P.M.).

Publ. n० 162 do Inst. Ocean da USP.

Contr. n 12 do G.P.P.M. 
O desembarque dos peixes capturados pelos barcos de pesca de Santos, que operam em várias regiões da costa sul do Brasil, é feito no Entreposto de Pesca de Santos. Os dados começaram a ser coletados nesse local em agôsto de 1958, mas o autor não os considera suficientes para tirar conclusões definitivas.

Apesar dos dados utilizados não apresentarem a exatidão desejada, é-nos possível analisar alguns fenômenos relacionados com a espécie estudada. Com a continuação dos estudos, que fazem parte de um programa a longo prazo, resultados mais seguros serão obtidos, o que virá auxiliar a indústria e a pesca através da avaliação dos estoques e de medidas de exploração e proteção aos mesmos.

\section{II - PESCA}

A pesca da corvina, efetuada pelos barcos de Santos, se faz ao longo da costa sul do Brasil, alcançando a costa do Uruguai, compreendendo desde o bloco de latitudes $23^{\circ}$ sul e $24^{\circ}$ sul e longitudes $44^{\circ}$ oeste e $45^{\circ}$ oeste até o bloco de latitudes $34^{\circ}$ sul e $35^{\circ}$ sul e longitudes $54^{\circ}$ oeste e $55^{\circ}$ oeste, como mostra a Figura 1 , restringindo-se a uma faixa de poucas milhas distante da costa (Braga, 1962; Richardson \& Moraes, 1960).

Os barcos pequenos atuam na costa de São Paulo, enquanto que os médios e grandes, tendo um raio de ação maior, atingem as áreas do sul, principalmente os grandes, que pescam na costa do Rio Grande do Sul e, algumas vêzes, na costa do Uruguai.

As áreas da costa sul são as que concorrem com a maior parte da corvina desembarcada em Santos (Richardson \& Moraes, op. cit.), devido à maior disponibilidade dessa espécie nessa região (Barcelos \& Richardson, 1960).

Não há estação pròpriamente dita para a pesca da corvina, que é feita durante o ano todo, havendo períodos de maior captura.

A corvina é desembarcada a granel, isto é, sem sofrer separação por categoria de tamanho, e nem sempre como espécie isolada, mas também integrando a mistura, onde são geralmente encontrados os exemplares imaturos junto com peixes adultos de pequeno porte, de várias espécies.

\section{III - CONSIDERAÇÕES GERAIS}

Foram colhidas oitenta (80) amostras de corvina, no Entreposto, durante o período de agôsto de 1958 a agôsto de 1959 , tendo sido medidos 10.521 peixes, num total de 79 caixas, com pêso médio de $50 \mathrm{~kg}$ por caixa. 
Os peixes foram medidos da ponta do focinho à extremidade da cauda, ligeiramente estendida, considerando-se classes de 0,50 em $0,50 \mathrm{~cm}$, sendo que as classes intermediárias foram agrupadas no meio centímetro inferior (por exemplo: peixes compreendidos entre 15,00 a $15,49 \mathrm{~cm}$ foram considerados como $15,00 \mathrm{~cm}$; entre $15,50$ e $15,99 \mathrm{~cm}$ foram considerados como $15,50 \mathrm{~cm})$.

Um certo número de peixes medidos foi enviado para o laboratório, e dêles se retiraram algumas escamas da região delimitada pela nadadeira peitoral esquerda. Para complementar o número de escamas obtidas dos peixes enviados ao laboratório, foram retiradas escamas de um certo número de peixes medidos no Entreposto. Não havendo, até a presente data, nenhum estudo a respeito da idade da corvina, foram examinadas muitas escamas nesse sentido.

Os peixes foram pesados no laboratório e agrupados em classes de $5 \mathrm{~g}$, a exemplo do que foi feito para os comprimentos.

Determinou-se o perímetro envolvendo-se a parte mais larga do peixe com um fio de barbante e, em seguida, mediu-se a porção do fio utilizada; foram consideradas classes de $0,50 \mathrm{em} 0,50 \mathrm{~cm}$, do mesmo modo que para os comprimentos.

A Tabela I mostra, para o período de agôsto de 1958 a agôsto de 1959, o movimento de desembarque em total de $\mathrm{kg}$, número de caixas e de peixes desembarcados, e o total de horas-lance, ou seja, o tempo efetivo em que a rêde permaneceu na água durante os arrastos, mostrando também a produção por hora-lance em $\mathrm{kg}$ e em número de peixes, e o movimento de amostragem.

Para se determinar, em número, o total de peixes desembarcados, basta dividir o pêso total desembarcado pelo pêso médio das caixas de onde os peixes foram examinados, obtendo-se assim o número total de caixas desembarcadas. Sabendo-se o número médio de peixes por caixa examinada, multiplica-se êste pelo número total de caixas desembarcadas, obtendo-se assim o número total de peixes desembarcados, por mês e por ano. Os dados sôbre o número médio de peixes capturados por hora-lance não foram considerados neste trabalho, porém, futuramente serão usados em estudos sôbre mortalidade.

A Tabela II mostra o número de corvinas desembarcadas, incluídas na mistura, durante o período de setembro de 1958 a agôsto de 1959, e suas porcentagens calculadas sôbre o total de corvinas desembarcadas no mesmo período. Para seis meses (setembro a dezembro, maio e junho) as porcentagens são baixas; para janeiro e fevereiro não há dados e, para quatro meses (março, abril, julho e agôsto), as porcentagens são altas. Deve-se ter em conta que a maior quantidade de mistura é capturada nas proximidades de Santos. 


\begin{tabular}{|c|c|c|c|c|c|c|c|c|c|c|c|c|c|c|c|}
\hline 兗 & 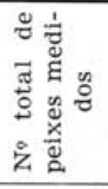 & $\begin{array}{l}\infty \\
\text { J゙ } \\
\text { i }\end{array}$ & ఊु & $\underset{\infty}{\infty}$ & $\begin{array}{l}\text { to } \\
\text { ti }\end{array}$ & ત્రુ & $\stackrel{\infty}{\not ్ n}$ & $\stackrel{ }{\circ}$ & न & జ్రి & $\underset{బ}{\infty}$ & 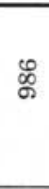 & $\vec{\sigma}$ & $\underset{\infty}{\infty}$ & $\begin{array}{l}\text { त్ } \\
\text { ณִ } \\
\text { ○े }\end{array}$ \\
\hline $\begin{array}{l}0 \\
4 \\
0 \\
1 \\
1 \\
02 \\
0 \\
5\end{array}$ & 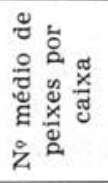 & $\underset{\sim}{\stackrel{g}{H}}$ & สี & Ф્⿹ & 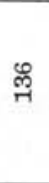 & $\stackrel{m}{7}$ & ঙ્స & $\stackrel{\infty}{\underset{7}{7}}$ & $\underset{\sim}{\stackrel{్}{\circ}}$ & 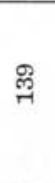 & 占 & 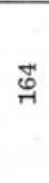 & ঙ્సి & $\stackrel{\varphi}{]}$ & $\underset{\mathrm{H}}{\mathrm{H}}$ \\
\hline$\varangle$ & 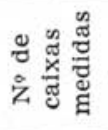 & $\stackrel{\circ}{i}$ & if & $\stackrel{\circ}{6}$ & 犬̂ & $\begin{array}{l}10 \\
10\end{array}$ & $\stackrel{\circ}{\sigma^{\prime}}$ & $\stackrel{\circ}{0}$ & $\stackrel{\circ}{*}$ & ${ }^{10}$ & is & 0 & $\stackrel{\circ}{i}$ & 요 & 오 \\
\hline \multirow{6}{*}{ 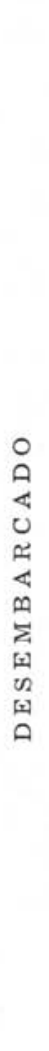 } & 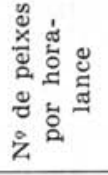 & $\underset{⿱ 乛}{\mathbb{N}}$ & 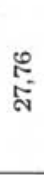 & $\begin{array}{l}\text { స్ } \\
\text { హీ }\end{array}$ & $\begin{array}{l}10 \\
\infty \\
102 \\
102\end{array}$ & $\begin{array}{l}\text { लొ } \\
\text { के }\end{array}$ & $\begin{array}{l}\text { \% } \\
\text { î }\end{array}$ & $\begin{array}{l}\text { b0 } \\
\text { ô }\end{array}$ & $\begin{array}{l}5 \\
\stackrel{\sigma}{\sigma}\end{array}$ & in & 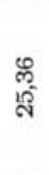 & $\begin{array}{l}\mathscr{\infty} \\
\tilde{m} \\
\tilde{m}\end{array}$ & $\begin{array}{l}\infty \\
\infty \\
0 \\
0 \\
+1\end{array}$ & $\begin{array}{l}\infty \\
\infty \\
\infty \\
\stackrel{0}{N}\end{array}$ & $\begin{array}{l}\text { స్ } \\
\text { సे }\end{array}$ \\
\hline & 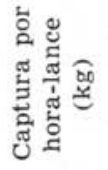 & $\begin{array}{l}0 \\
\infty \\
\infty\end{array}$ & $\begin{array}{l}\infty \\
\vec{f} \\
-1\end{array}$ & $\begin{array}{l}\infty \\
\infty \\
\sigma^{2}\end{array}$ & $\begin{array}{l}\text { ณ̂ } \\
\text { के }\end{array}$ & $\begin{array}{l}\text { in } \\
\infty \\
\infty\end{array}$ & 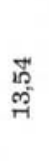 & స્ & $\begin{array}{l}\biguplus_{\infty}^{\prime} \\
\end{array}$ & $\underset{\text { \ֶ. }}{\mathbb{2}}$ & $\underset{\infty}{\stackrel{8}{\circ}}$ & ले & जิ & $\begin{array}{l}\text { స్ } \\
\text { సี }\end{array}$ & స్ \\
\hline & 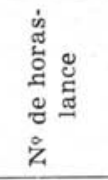 & 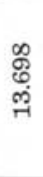 & $\begin{array}{l}\stackrel{0}{*} \\
\infty \\
0 \\
0 \\
+1\end{array}$ & 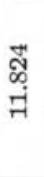 & 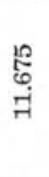 & 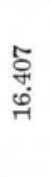 & $\begin{array}{l}\underset{F}{E} \\
\underset{F}{ }\end{array}$ & ஸે & $\begin{array}{l}\text { ส্ড } \\
\underset{ন}{-}\end{array}$ & 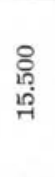 & $\begin{array}{l}\text { ఫ్ } \\
\text { స్త }\end{array}$ & 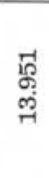 & $\begin{array}{l}\text { S. } \\
\stackrel{0}{0} \\
\stackrel{0}{-1}\end{array}$ & $\begin{array}{l}\infty \\
\stackrel{\infty}{0} \\
\dot{\sigma}\end{array}$ & 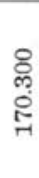 \\
\hline & 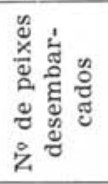 & $\begin{array}{l}\text { ஜ } \\
0 \\
\text { त. } \\
\text { مू }\end{array}$ & 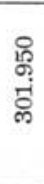 & 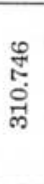 & 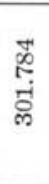 & 莡 & \begin{tabular}{l} 
స్ల్ \\
\multirow{్}{*}{}
\end{tabular} & 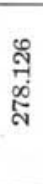 & 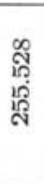 & $\begin{array}{l}\stackrel{1}{\infty} \\
\infty \\
\text { నิ่ } \\
\text { ลิ }\end{array}$ & 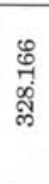 & 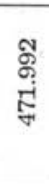 & 官 & 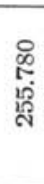 & 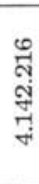 \\
\hline & 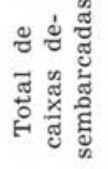 & $\begin{array}{l}\text { ڤ్ల } \\
\text { ஸे }\end{array}$ & 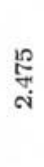 & $\begin{array}{l}\text { ले } \\
\text { ஸे }\end{array}$ & ન્ને & $\begin{array}{l}\stackrel{0}{0} \\
\text { ஸ் }\end{array}$ & 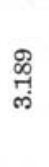 & 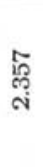 & 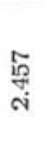 & $\begin{array}{l}\text { న్ } \\
\text { ర़ } \\
\text { - }\end{array}$ & స్․․ & 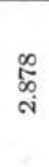 & $\begin{array}{l}\text { స్ } \\
\text { ㄱ. }\end{array}$ & $\begin{array}{l}\text { ํㅗ } \\
\text { ส่ }\end{array}$ & $\begin{array}{l}\text { हे } \\
\text { ले } \\
\text { ले }\end{array}$ \\
\hline & 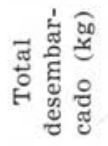 & $\begin{array}{l}\infty \\
\infty \\
\infty \\
\infty \\
\infty \\
\neq\end{array}$ & $\begin{array}{l}\stackrel{\Re}{N} \\
\text { ָ̦ }\end{array}$ & $\begin{array}{l}\text { 令 } \\
\text { in } \\
\end{array}$ & 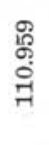 & 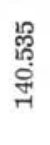 & $\begin{array}{l}\text { 号 } \\
\text { 官 } \\
\text { मी }\end{array}$ & $\begin{array}{l}\stackrel{8}{0} \\
\stackrel{0}{\leftarrow} \\
7\end{array}$ & $\begin{array}{l}\text { ळ } \\
\infty \\
\text { స్ } \\
\text { సె }\end{array}$ & $\begin{array}{l}\overrightarrow{6} \\
\stackrel{\infty}{\infty}\end{array}$ & 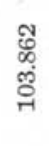 & 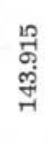 & $\begin{array}{l}\frac{\pi}{5} \\
\text { त् }\end{array}$ & 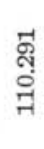 & $\begin{array}{l}\text { సี } \\
\text { กิ } \\
\text { กุ }\end{array}$ \\
\hline & $\mathbb{L}_{\Sigma}^{\infty}$ & 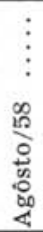 & है & $\begin{array}{l}: \\
\circ \\
\stackrel{\circ}{3} \\
0 \\
0\end{array}$ & 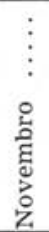 & 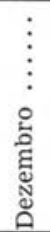 & 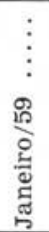 & 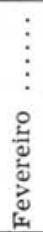 & 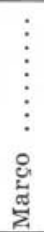 & $\begin{array}{c}\vdots \\
\vdots \\
\vdots \\
\vdots \\
\overline{\mathbf{L}} \\
\end{array}$ & $\frac{\mathrm{J}}{\mathrm{J}}$ & 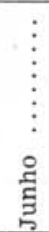 & $\vdots$ & $\begin{array}{l}\vdots \\
\vdots \\
\vdots \\
\circ \\
\stackrel{5}{8} \\
\stackrel{8}{8} \\
\&\end{array}$ & : \\
\hline
\end{tabular}




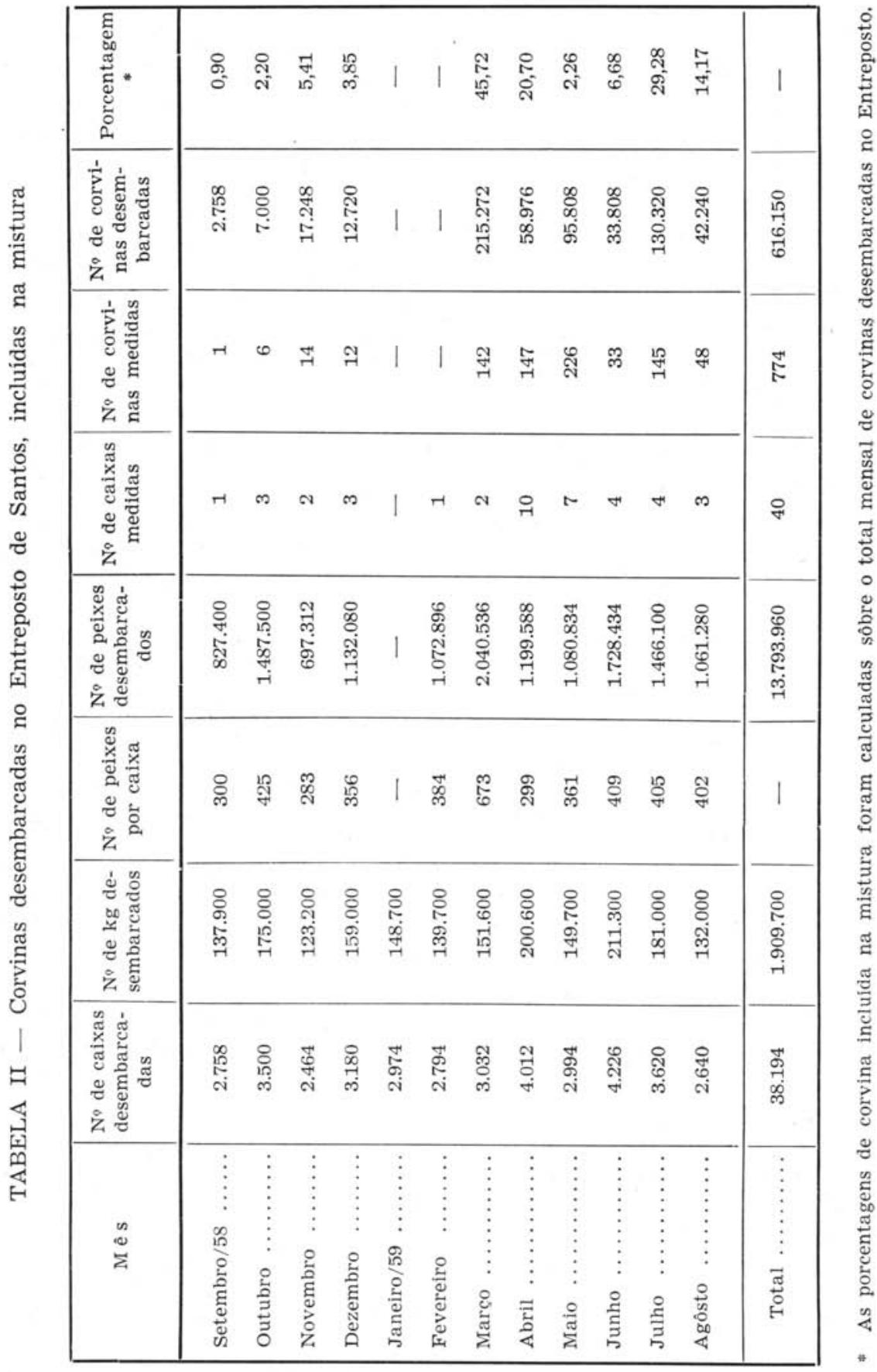


Para melhor entendimento do movimento de desembarque de corvina e de outros peixes de valor comercial, no Entreposto de Pesca de Santos, consulte-se Richardson \& Moraes (1960).

A Tabela III mostra o número de peixes examinados para a obtenção dos dados básicos sôbre idade, perímetro e pêso.

TABELA III - Número de peixes examinados durante o período de agôsto de 1958 a agôsto de 1959, para coleta de dados referentes a idade, perímetro e pêso

\begin{tabular}{|c|c|c|c|c|}
\hline \multirow{2}{*}{ A no } & \multirow{2}{*}{ M ê s } & \multicolumn{3}{|c|}{ No de peixes examinados para: } \\
\hline & & Idade & Perimetro & Pêso \\
\hline 1958 & $\begin{array}{l}\text { Agôsto } \ldots \ldots \cdots \\
\text { Setembro } \ldots \ldots \cdots \\
\text { Outubro } \ldots \ldots \cdots \\
\text { Novembro } \\
\text { Dezembro } \ldots \ldots\end{array}$ & $\begin{array}{r}148 \\
127 \\
78 \\
182 \\
58\end{array}$ & $\begin{array}{r}- \\
2 \\
9 \\
23 \\
21\end{array}$ & $\begin{array}{r}- \\
30 \\
9 \\
28 \\
21\end{array}$ \\
\hline 1959 & 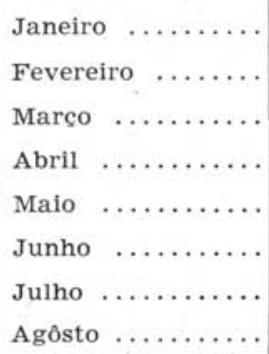 & $\begin{array}{r}58 \\
80 \\
83 \\
170 \\
175 \\
242 \\
242 \\
249\end{array}$ & $\begin{array}{r}13 \\
14 \\
38 \\
170 \\
175 \\
242 \\
242 \\
249\end{array}$ & $\begin{array}{l}14 \\
19 \\
21 \\
17 \\
29 \\
38 \\
54 \\
36\end{array}$ \\
\hline & Total $\ldots \ldots \ldots$ & 1.892 & 1.198 & 316 \\
\hline
\end{tabular}

\section{IV - MÉTODOS, DADOS E SUA DISCUSSÃO}

DISTRIBUIÇÃo DOS COMPRIMENTOS - A Tabela IV mostra a distribuição percentual mensal dos comprimentos da corvina medida no Entreposto. Os comprimentos foram agrupados em classes de 2 em $2 \mathrm{~cm}$; as classes de comprimentos ímpares nas classes de comprimentos pares imediatamente inferiores; por exemplo: as classes de 19 e $21 \mathrm{~cm}$ foram agrupadas nas classes de 18 e $20 \mathrm{~cm}$ respectivamente. 


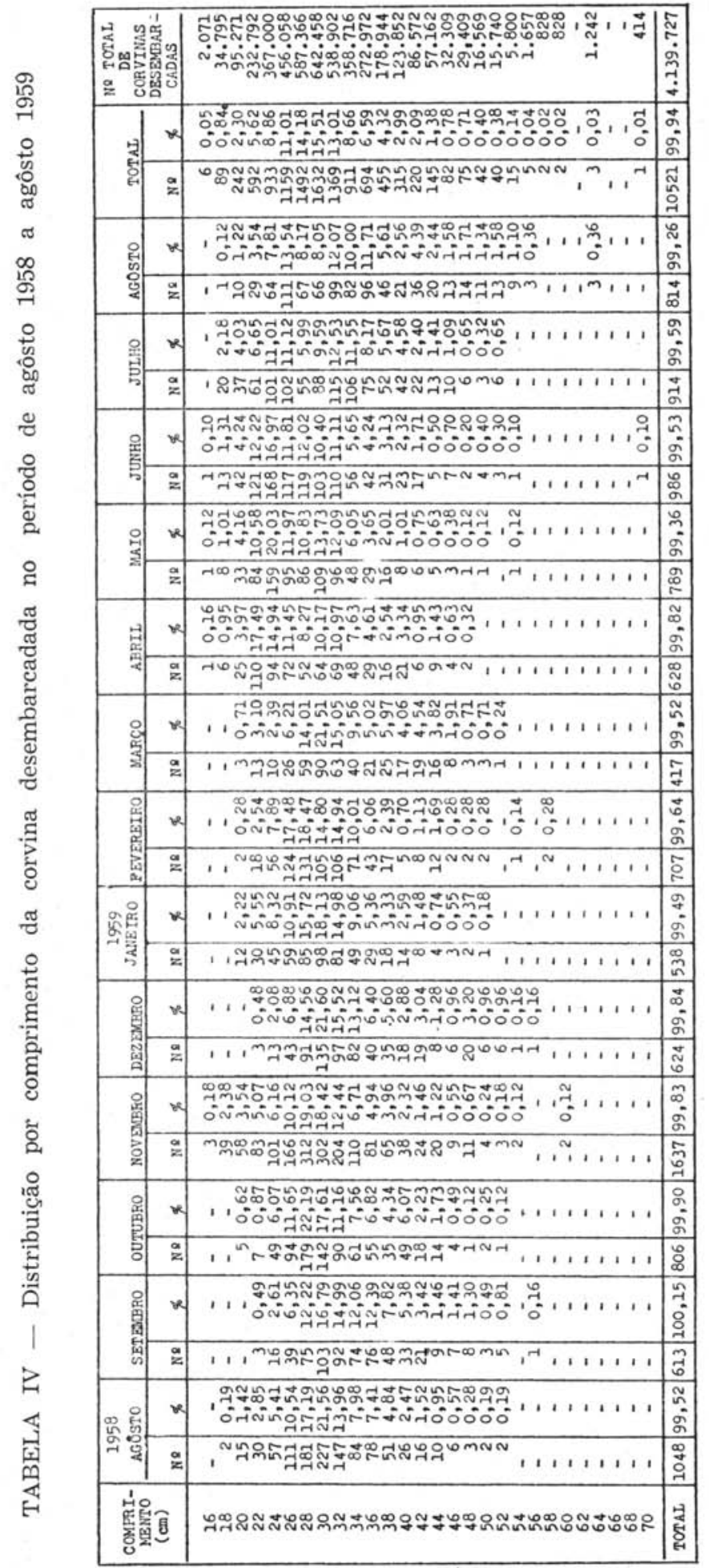




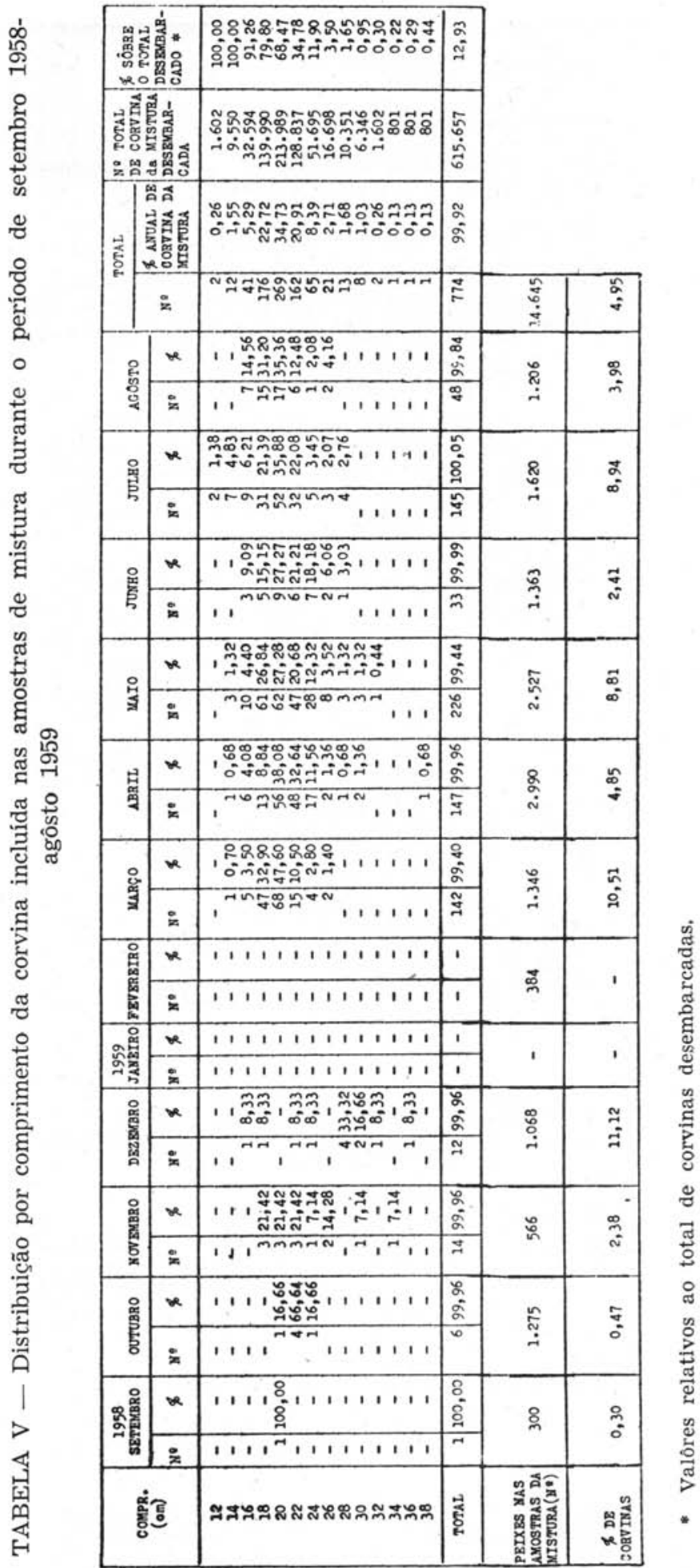


A mesma Tabela IV dá a distribuição do total de peixes medidos no Entreposto e também o número total desembarcado, no período de agôsto de 1958 a agôsto de 1959 .

A Tabela $\mathrm{V}$ mostra a distribuição mensal, em número e porcentagem, dos comprimentos de corvinas encontradas na mistura, durante o período de setembro de 1958 a agôsto de 1959, sendo que não houve amostragem em agôsto de 1958. Mostra, também, a porcentagem de corvinas dentro das amostras de mistura, bem como a distribuição percentual anual e em número, para o total desembarcado (Tabela II) por grupo de comprimento. A última coluna da Tabela IV e a penúltima da Tabela $\mathrm{V}$ permitem obter a quantidade, em têrmos de percentagem, por grupo de comprimento, da corvina da mistura sôbre o total de corvinas desembarcadas.

A Figura 2 mostra as curvas de distribuição de comprimentos, com correção de $1 \mathrm{~cm}$, para a corvina e a porção dessa espécie englobada na mistura, desembarcadas durante o período de agôsto de 1958 a agôsto de 1959 .

Observa-se que a corvina, na mistura, tem por limites 12 e $38 \mathrm{~cm}$, com valor modal de $20,4 \mathrm{~cm}$; entretanto, o lado esquerdo da curva é pouco significativo, pois corresponde a comprimentos de peixes maiores devido à seleção efetuada pelos pescadores; os peixes menores são rejeitados.

A Figura 3 mostra a distribuição mensal dos comprimentos da corvina, conforme os dados da Tabela IV, não tendo sido considerados os valôres da Tabela $\mathrm{V}$ por serem pouco representativos na figura, exceto em alguns meses onde as porcentagens são relativamente altas.

Dois períodos podem ser observados: o período de agôsto de 1958 a março de 1959 , onde as curvas mensais mostram uma moda principal, cujos valôres mensais oscilam pouco; o segundo, de abril a agôsto de 1959, cujos valôres modais principais tendem a se deslocar para a direita. A partir de abril aparece, para o lado esquerdo das curvas, um valor modal que representa uma classe de peixes pequenos. Êsse aparecimento súbito e a permanência dessa nova classe modal nos meses seguintes sugere o recrutamento de peixes pequenos por volta do mês de abril. Consultando-se a Tabela $\mathrm{V}$ nota-se que em março aparecem peixes pequenos, confirmando o que foi dito para o recrutamento.

Considerando-se os comprimentos médios mensais (Tabela VI e Fig. 4), verifica-se que, de agôsto de 1958 a março de 1959, há flutuação de mês para mês, sem tendência nítida de elevar-se. O início dêsse período coincide com o aparecimento da classe de peixes pequenos, e o fim pode ser interpretado como sendo o de cres- 
cimento ou de imigração de peixes de tamanho grande, período êsse que corresponde ao outono e parte do inverno para o Hemisfério Sul.

TABELA VI - Médias de comprimentos mensais (corvina).

\begin{tabular}{|c|c|c|}
\hline A no & M ês & $\begin{array}{l}\text { Médias de } \\
\text { comprimento } \\
(\mathrm{cm})^{*}\end{array}$ \\
\hline 1958 & $\begin{array}{l}\text { Agôsto } \ldots . . . \\
\text { Setembro } \\
\text { Outubro } \ldots \\
\text { Novembro } \\
\text { Dezembro }\end{array}$ & $\begin{array}{l}31,49 \\
34,05 \\
31,85 \\
30,55 \\
33,67\end{array}$ \\
\hline 1959 & $\begin{array}{l}\text { Janeiro } \ldots \ldots \\
\text { Fevereiro } \ldots \ldots \\
\text { Marco } \ldots \ldots \\
\text { Abril } \ldots \ldots \\
\text { Maio } \ldots \ldots \\
\text { Junho } \ldots \ldots \\
\text { Julho } \ldots \ldots \\
\text { Agôsto } \ldots \ldots \\
\text { An. }\end{array}$ & $\begin{array}{l}30,75 \\
30,88 \\
33,32 \\
29,06 \\
28,66 \\
29,01 \\
31,18 \\
33,70\end{array}$ \\
\hline
\end{tabular}

* Calculadas para classes de 0,5 em 0,5 cm.

Lançados os valôres modais mais acentuados das curvas mensais de distribuição de comprimentos para a corvina, como se observa na Figura 5, verifica-se que de agôsto de 1958 a março de 1959 os valôres modais mostram uma linha que não apresenta tendência e que a partir de abril de 1959 torna-se ascendente. Nesse último período é também ascendente a linha dos valôres modais das classes de peixes pequenos. Isto sugere que a corvina tem por época de crescimento o período compreendido entre abril (ou antes) e agôsto (ou até mais tarde), ou que êsse período corresponde ao de imigração dos peixes maiores na área de pesca. Mostra também a existência de duas classes modais mais evidentes, sendo uma delas correspondente à classe de peixes pequenos.

IDADE - A determinação da idade é importante para se conhecer o crescimento do peixe e a taxa de mortalidade por grupo de idade, possibilitando a avaliação do volume do estoque. 
Inúmeros são os trabalhos que mostram ser possível a determinação da idade de peixes de águas frias através do exame de suas partes duras, tais como: vértebras, otolitos e escamas, onde podem ser observadas marcas concêntricas, em forma de anel, formadas periòdicamente.

Para o Atlântico Sul Ocidental, onde as águas são quentes, dois estudos foram feitos, mostrando ser possível a observação de anéis de formação periódica nas escamas. Êsses estudos se referem à sardinha (Sardinella allecia) e à pescada-foguete (Macrodon ancylodon) feitos por Richardson et al. (1959) e Lara (1951), respectivamente.

Com base nas observações dos citados autores foram feitos estudos sôbre escamas de corvina, com a finalidade de se determinar sua idade. Para isso, durante as medições (de comprimento, perímetro, etc.) efetuadas no Entreposto, foram coletadas amostras de escamas com o mesmo número de peixes para cada comprimento. De cada peixe foram selecionadas duas escamas da região delimitada pela nadadeira peitoral esquerda, onde se localizam as escamas melhor formadas. Êsses cuidados foram tomados (mesmo número de peixes para cada comprimento e retirada de escamas da mesma região) para que cada comprimento estivesse bem representado dentro de cada grupo de idade. Para reduzir o mais possível o êrro devido à má formação de escamas, o número delas foi aumentado de acôrdo com o tempo disponível para isso.

A coleta de escamas foi efetuada durante o período de agôsto de 1958 a agôsto de 1959, sendo retiradas de tôdas as amostras mensais, num total de 1.994 peixes, incluindo corvinas (Tabela III) e corvinas englobadas na mistura (102 peixes).

As escamas foram tratadas da seguinte maneira:

1 - Lâmina de vidro para exame microscópico, bem limpa, sôbre a qual se passou uma fina camada de albumina para a adesão das escamas; uma etiquêta com o número de ordem dos peixes foi colocada numa das extremidades da lâmina.

2 - As escamas foram lavadas em água corrente e duas das melhores, de cada peixe, foram colocadas na lâmina; esta comporta escamas de cinco peixes, sendo duas de cada.

3 - Outra lâmina, bem limpa, foi justaposta à preparação, e as extremidades das lâminas foram unidas com fita adesiva.

No exame das escamas foi utilizado um microprojetor Wetzlar com objetiva $3 \times$ e ocular $4 \times$. A fim de se manter constante 
o aumento, o projetor foi fixado a determinada distância da tela, de modo a fornecer um foco de luz de $11 \mathrm{~cm}$ de diâmetro. No caso das escamas maiores que o campo óptico, que não forneciam imagem completa, movia-se a lâmina para completar a imagem.

Foram observadas marcas nas escamas, em forma de anel, conforme mostra a Figura 6 , as quais foram consideradas periódicas, como se verá mais adiante. $\mathrm{O}$ fator determinante da formação de tais marcas ou anéis não é conhecido.

Escamas de 1.892 peixes foram lidas duas vêzes. Na primeira leitura foi registrado sòmente o número de anéis existentes em cada escama. A segunda leitura, independente da primeira, foi feita para obtenção mais segura do número de anéis. Comparados os resultados da primeira e da segunda leituras foi possível selecionar escamas de 969 peixes, que não apresentaram discrepâncias quanto à leitura do número de anéis observados.

As 923 escamas que apresentaram dificuldades de leitura não foram consideradas. Para complementar os dados com relação aos peixes pequenos fêz-se uso de corvinas englobadas na mistura, das quais se examinaram escamas de 102 peixes, correspondendo ao período de novembro de 1958 a agôsto de 1959, como se vê na Tabela VII. Foi obtida a distribuição dos comprimentos por grupo de anel, para um total, de 1.071 peixes. Essa distribuição e o total de peixes medidos no Entreposto (10.521) foram usados como chave para a obtenção dos comprimentos por grupo de anel, para o total de peixes desembarcados, tendo sido agrupadas a corvina e a corvina englobada na mistura (4.758.366 peixes - Tabelas I e II). As médias de comprimento por grupo de anel foram calculadas sôbre o total desembarcado, para atenuar os efeitos da seleção existente para os peixes pequenos. Êsses dados são vistos na Tabela VIII.

Considerados os valôres da Tabela VIII, foram calculados o desvio padrão e o êrro padrão da média, por grupo de anel, que permitem avaliar a significância das mesmas.

Dessa forma observa-se que os valôres do êrro padrão são relativamente baixos para as classes de $0,1,2,3,4$ e 5 anéis. Entretanto, para as classes de 0 e 1 anel há vícios de amostragem, devido à seleção feita pelos pescadores, malha das rêdes ou por causa da variação dos locais de pesca, que possibilitaram somente a observação de peixes de maior comprimento para essas classes.

O método do "retro-cálculo" (back-calculation) foi usado, como veremos mais adiante, para se obter o comprimento dos peixes de 0 e 1 anel. Para as classes acima de 5 anéis os valôres do êrro padrão apresentam-se altos, possivelmente devido ao pequeno número de peixes examinados. 
TABELA VII - Distribuição total dos comprimentos e médias de comprimento por grupo de anel, da corvina da mistura

\begin{tabular}{|c|c|c|c|c|c|c|}
\hline \multirow{2}{*}{$\begin{array}{l}\text { Comp. } \\
\text { (cm) }\end{array}$} & \multicolumn{5}{|c|}{ A NEIS } & \multirow{2}{*}{ Total } \\
\hline & 0 & 1 & 2 & 3 & 4 & \\
\hline 15 & 4 & - & - & - & - & 4 \\
\hline 16 & 2 & - & - & - & - & 2 \\
\hline 17 & 3 & - & - & - & 一 & 3 \\
\hline 18 & 10 & - & - & - & - & 10 \\
\hline 19 & 11 & 1 & - & - & - & 12 \\
\hline 20 & 15 & 2 & - & - & - & 17 \\
\hline 21 & 5 & 2 & - & - & - & 7 \\
\hline 22 & 2 & 5 & 1 & - & - & 8 \\
\hline 23 & 2 & 9 & - & - & - & 11 \\
\hline 24 & 2 & 4 & 4 & - & - & 10 \\
\hline 25 & - & - & 4 & 一 & - & 4 \\
\hline 26 & 1 & 1 & 4 & 一 & - & 6 \\
\hline 27 & - & - & - & 一 & - & - \\
\hline 28 & - & - & 1 & - & - & 1 \\
\hline 29 & - & - & - & 2 & - & 2 \\
\hline 30 & - & - & - & 2 & 1 & 3 \\
\hline 31 & - & - & - & 一 & - & - \\
\hline 32 & - & - & - & - & - & $\perp$ \\
\hline 33 & - & 一 & - & 1 & - & 1 \\
\hline 39 & 一 & - & - & - & 1 & 1 \\
\hline Total & 57 & 24 & 14 & 5 & 2 & 102 \\
\hline $\bar{X}$ & 19,81 & 23,00 & 25,50 & 30,70 & 35,00 & - \\
\hline
\end{tabular}

* Médias de comprimento com correção de $+0,50 \mathrm{~cm}$.

Com o uso do método do "retro-cálculo" foi possível obter-se os comprimentos dos peixes de cada grupo de anel, tendo-se procedido da seguinte maneira: para a obtenção da distância relativa entre o foco da escama e cada anel fêz-se uso de tiras de papel, com um traço no centro, no sentido do maior comprimento. $\mathrm{Nu}$ ma das extremidades anotou-se o número da amostra e o número de ordem do peixe. Na projeção, na outra extremidade da tira, a extremidade do traço foi colocada sôbre o foco da escama; o 
bordo da escama, projetado na tira, foi marcado sôbre o traço e anotado o comprimento do peixe. Ao longo do traço foram marcadas as posições dos anéis.

TABELA VIII - Distribuição de comprimentos por grupo de anel para o total de corvina desembarcada e médias de comprimento* por grupo de anel

\begin{tabular}{|c|c|c|c|c|c|c|c|c|c|c|c|c|}
\hline \begin{tabular}{c|} 
COMPRINENTO \\
$(\mathrm{cm})$
\end{tabular} & 0 ANEL & 1. ANEL & 20 ANEL & $3^{\circ}$ ANEL & $4^{\circ}$ ANEL & $5 \circ$ ANEI & $60 \mathrm{NBSL}$ & $70 \mathrm{ANEL}$ & $82 \mathrm{ANEL}$ & $\theta \circ$ ANES & $100 \mathrm{ANEL}$ & 11 QNESE \\
\hline 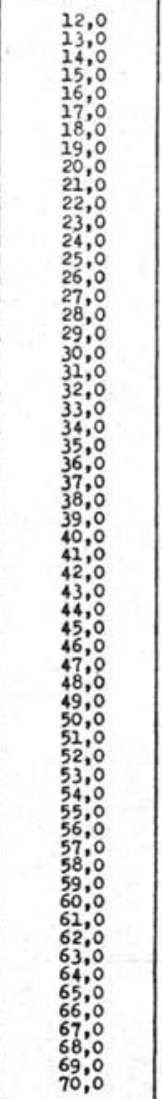 & $\begin{array}{r}801 \\
801 \\
4.775 \\
4: 775 \\
17.332 \\
17.332 \\
87.392 \\
59: 580 \\
85: 905 \\
56.594 \\
25.828 \\
28.928 \\
27.012 \\
6.220 \\
\vdots \\
\vdots \\
\vdots \\
\vdots \\
\vdots \\
\vdots \\
\vdots \\
\vdots \\
\vdots \\
\vdots \\
\vdots \\
\vdots \\
\vdots \\
\vdots \\
\vdots \\
\vdots \\
\vdots \\
\vdots \\
\vdots \\
\vdots \\
\vdots \\
\vdots\end{array}$ & $\begin{array}{c}\vdots \\
\vdots \\
\vdots \\
23.832 \\
231 \\
51.543 \\
72.156 \\
109.769 \\
97.632 \\
74.283 \\
61.570 \\
.55980 \\
24.120 \\
54.977 \\
5.639 \\
5: 318 \\
\vdots \\
\vdots \\
\vdots \\
\vdots \\
\vdots \\
\vdots \\
\vdots \\
\vdots \\
\vdots \\
\vdots \\
\vdots \\
\vdots \\
\vdots \\
\vdots \\
\vdots \\
\vdots \\
\vdots \\
\vdots \\
\vdots \\
\end{array}$ & $\begin{array}{l}= \\
\vdots \\
\vdots \\
\vdots \\
53.972 \\
17.181 \\
25.770 \\
45.199 \\
50.624 \\
94.542 \\
123.140 \\
130.620 \\
159.192 \\
167.356 \\
146.614 \\
122.314 \\
82.470 \\
60.495 \\
54.050 \\
13.827 \\
3: 908 \\
6: 366 \\
6: 844 \\
7.095 \\
\vdots \\
\vdots \\
\vdots \\
\vdots \\
\vdots \\
\vdots \\
\vdots \\
\vdots \\
\vdots \\
\vdots \\
\vdots \\
\vdots \\
\vdots \\
\vdots \\
\vdots \\
\vdots \\
\vdots \\
\vdots \\
\vdots \\
\vdots\end{array}$ & $\begin{array}{l}\vdots \\
\vdots \\
\vdots \\
\vdots \\
\vdots \\
\vdots \\
\vdots 3.616 \\
133.506 \\
24.628 \\
43.540 \\
48.240 \\
125.517 \\
129.697 \\
186.130 \\
197.928 \\
157.287 \\
118.910 \\
82.962 \\
71.424 \\
66.843 \\
23.954 \\
18.920 \\
6.656 \\
44.424 \\
14.075 \\
2.164 \\
2.164 \\
\vdots \\
\vdots \\
\vdots \\
\vdots \\
\vdots \\
\vdots\end{array}$ & $\begin{array}{c}\vdots \\
\vdots \\
\vdots \\
\vdots \\
\vdots \\
\vdots \\
\vdots \\
\vdots \\
5.824 \\
16.917 \\
10.636 \\
43.984 \\
48.396 \\
59: 455 \\
59.917 \\
75.392 \\
68.026 \\
42.570 \\
66.560 \\
28.756 \\
14.075 \\
12.366 \\
8.656 \\
2.858 \\
5.715 \\
1.795 \\
\vdots \\
\vdots \\
\vdots \\
\vdots \\
\vdots \\
\vdots \\
\vdots \\
\vdots \\
\vdots \\
\vdots \\
\vdots \\
\vdots \\
\vdots \\
\end{array}$ & $\begin{array}{l}\vdots \\
\vdots \\
\vdots \\
\vdots \\
\vdots \\
\vdots \\
\vdots \\
\vdots \\
\vdots \\
\vdots \\
\vdots \\
37.033 \\
23.045 \\
31: 744 \\
15: 915 \\
17.110 \\
36.190 \\
17.696 \\
15.890 \\
10.305 \\
12.984 \\
8: 574 \\
5.715 \\
\vdots \\
\vdots \\
\vdots \\
\vdots \\
\vdots \\
\vdots \\
\vdots \\
\vdots \\
\vdots \\
\vdots \\
\vdots \\
\vdots \\
\vdots \\
\vdots \\
\end{array}$ & $\begin{array}{c}\vdots \\
\vdots \\
\vdots \\
\vdots \\
\vdots \\
\vdots \\
\vdots \\
\vdots \\
\vdots \\
\vdots \\
\vdots \\
\vdots \\
\vdots \\
\vdots \\
\overline{6} .366 \\
13.688 \\
13.312 \\
6.636 \\
8.445 \\
10.805 \\
8.574 \\
5.75 \\
5.385 \\
7.352 \\
8.284 \\
\vdots \\
7.870 \\
\vdots \\
\vdots \\
\vdots \\
\vdots \\
\vdots \\
\vdots \\
\vdots \\
\vdots \\
\vdots \\
\vdots \\
\end{array}$ & $\begin{array}{l}\vdots \\
\vdots \\
\vdots \\
\vdots \\
\vdots \\
\vdots \\
\vdots \\
\vdots \\
\vdots \\
\vdots \\
\vdots \\
\vdots \\
\vdots \\
5.183 \\
6: 844 \\
4: 730 \\
2.212 \\
2: 815 \\
4.122 \\
6: 492 \\
5.716 \\
5.715 \\
8.154 \\
7.575 \\
4.901 \\
\vdots \\
4.722 \\
\vdots \\
\vdots \\
\vdots \\
\vdots \\
\vdots \\
\vdots \\
\vdots \\
\vdots \\
\vdots \\
\vdots \\
\vdots \\
\end{array}$ & $\begin{array}{l}\vdots \\
\vdots \\
\vdots \\
\vdots \\
\vdots \\
\vdots \\
\vdots \\
\vdots \\
\vdots \\
\vdots \\
\vdots \\
\vdots \\
\vdots \\
\vdots \\
2.365 \\
5 \\
5.630 \\
6.183 \\
2.164 \\
5.715 \\
\vdots \\
4.901 \\
2.761 \\
\vdots \\
2.900 \\
\vdots \\
\vdots \\
\vdots \\
\vdots \\
\vdots \\
\vdots \\
\vdots \\
\vdots \\
\vdots \\
\end{array}$ & $\begin{array}{l}\vdots \\
\vdots \\
\vdots \\
\vdots \\
\vdots \\
\vdots \\
\vdots \\
\vdots \\
\vdots \\
\vdots \\
\vdots \\
\vdots \\
\vdots \\
\vdots \\
\vdots \\
\vdots \\
\vdots \\
\vdots \\
2.858 \\
\vdots \\
\vdots \\
\vdots \\
\vdots \\
1.574 \\
2.900 \\
-828 \\
828 \\
-414 \\
\vdots \\
\vdots \\
\vdots \\
\vdots \\
\vdots \\
\vdots\end{array}$ & $\begin{array}{l}\vdots \\
\vdots \\
\vdots \\
\vdots \\
\vdots \\
\vdots \\
\vdots \\
\vdots \\
\vdots \\
\vdots \\
\vdots \\
\vdots \\
\vdots \\
\vdots \\
\vdots \\
\vdots \\
\vdots \\
\vdots \\
4.901 \\
5.522 \\
\vdots \\
\vdots \\
\vdots \\
\vdots \\
\vdots \\
\vdots \\
\vdots \\
\vdots \\
\vdots \\
\vdots \\
\end{array}$ & $\begin{array}{l}\vdots \\
\vdots \\
\vdots \\
\vdots \\
\vdots \\
\vdots \\
\vdots \\
\vdots \\
\vdots \\
\vdots \\
\vdots \\
\vdots \\
\vdots \\
\vdots \\
\vdots \\
\vdots\end{array}$ \\
\hline FOIAL & 423.375 & 587.819 & 1320.569 & 1340.421 & 641.338 & 252.644 & 112.752 & 83.933 & 32.619 & 21.614 & 10.837 & 4.058 \\
\hline $\bar{x}(\cdot)$ & 20,31 & 23,59 & 28,06 & 32,25 & 36,11 & 37,98 & 43,39 & 44,77 & 45,59 & 50,63 & 50,83 & 59,89 \\
\hline DESVIO PADRÃO & 2,4 & 2,3 & 3,42 & 3,35 & 3,48 & 3,36 & 4,84 & 4,23 & 4,78 & 6,55 & 3,49 & 6,43 \\
\hline ÊRRO PADRTOO & 0,003 & $0, \infty 03$ & 0,003 & 0,003 & 0,004 & 0,007 & 0,014 & 0,014 & 0,026 & 0,031 & 0,017 & 0,102 \\
\hline
\end{tabular}

- Médias com correção de meio centímetro. 
A pasição de cada anel, em centímetros, tendo por base o valor conhecido do bordo, correspondente ao comprimento total do peixe, foi determinado com o uso de uma régua que tem as seguintes características: num tabuleiro de $60 \times 60 \mathrm{~cm}$ fixou-se uma régua milimetrada num dos bordos; uma haste móvel, de bordos bem retilíneos e com a extremidade afilada em cunha, foi ajustada num encaixe situado no ângulo oposto ao zero da régua, de tal maneira que a haste podia ser deslocada ao longo da régua, sem se afastar do encaixe. $O$ bordo compreendido entre o encaixe da haste e o zero da régua tinha um prolongamento do encaixe, onde se ajustou a base da tira de papel.

Para a leitura da posição dos anéis marcados na tira colocou-se o bordo inferior da haste sôbre o valor correspondente ao bordo da escama, na régua milimetrada; a seguir, colocou-se a tira de papel sôbre o tabuleiro e ajustou-se o traço correspondente ao bordo da escama, ao bordo inferior da haste móvel; dessa maneira, mantendo-se fixa a tira, deslocou-se a haste para as várias marcas correspondentes aos anéis, e leu-se na régua milimetrada o valor correspondente a cada anel (Figura 7).

TABELA IXa - Médias de comprimento determinadas por retro-cálculo (back-calculation), por grupo de anel.

\begin{tabular}{|c|c|c|c|c|c|c|c|c|c|}
\hline & \multicolumn{8}{|c|}{ A NEIS } & \multirow{2}{*}{$\begin{array}{l}\text { No de } \\
\text { peixes }\end{array}$} \\
\hline & 10 & 29 & 30 & $4^{\circ}$ & $5^{\circ}$ & $6^{\circ}$ & $7 \circ$ & $8^{\circ}$ & \\
\hline 1 anel $\ldots \ldots$. & 17,6 & - & - & - & - & - & - & - & 42 \\
\hline 2 anéis $\ldots \ldots$ & 16,1 & 23,7 & - & - & - & - & - & - & 167 \\
\hline 3 anéis $\ldots \ldots$ & 16,2 & 23,7 & 29,4 & - & - & - & - & - & 155 \\
\hline 4 anéis $\ldots$ & 17,0 & 24,4 & 30,2 & 34,3 & - & - & - & - & 100 \\
\hline 5 anéis .. & 17,9 & 25,2 & 30,8 & 34,6 & 37,5 & - & - & - & 46 \\
\hline 6 anéis $\ldots \ldots$ & 16,7 & 24,0 & 29,8 & 33,9 & 38,2 & 41,5 & - & - & 18 \\
\hline 7 anéis $\ldots .$. & 18,7 & 26,5 & 32,1 & 36,1 & 39,1 & 41,2 & 43,7 & - & 16 \\
\hline 8 anéis $\ldots \ldots$ & 18,5 & 25,5 & 30,5 & 34,0 & 37,1 & 40,0 & 42,4 & 44,4 & 6 \\
\hline $\begin{array}{l}\text { Média total por } \\
\text { anel }\end{array}$ & 16,7 & 24,1 & 30,0 & 34,4 & 37,9 & 41,3 & 43,3 & 44,4 & - \\
\hline No de peixes. & 550 & 508 & 341 & 186 & 86 & 40 & 22 & 6 & 一 \\
\hline
\end{tabular}

Das escamas dos 969 peixes, selecionados pelas duas leituras, foram escolhidas 550 escamas, que mostraram anéis bem visíveis, com as quais foram obtidos os dados para o "retro-cálculo" (Tabela IXa). Nesta tabela estão representados os comprimentos 


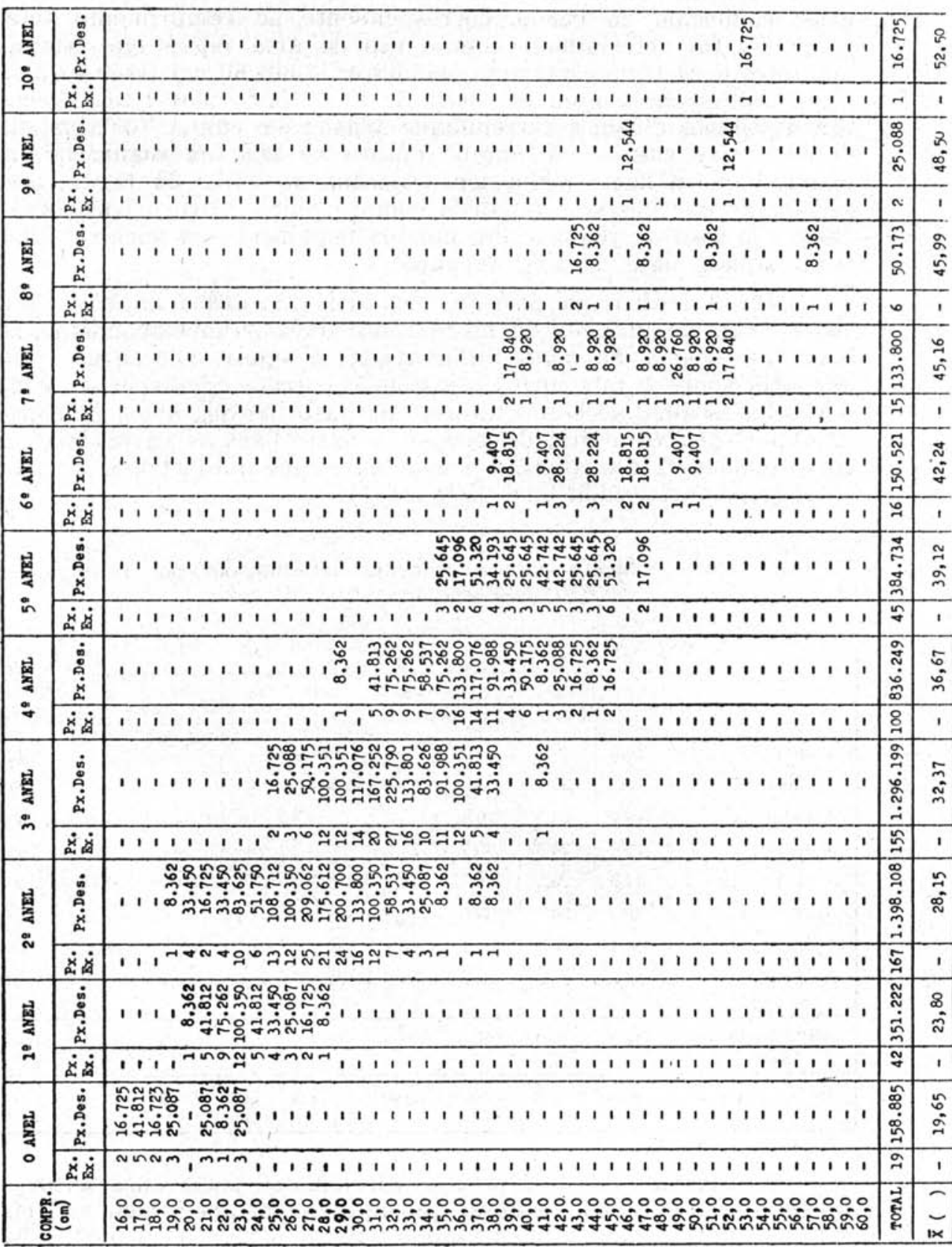


médios obtidos para cada anel, das escamas de 1, 2, 3 e mais anéis, bem como os comprimentos médios por grupo de anel. Os cálculos foram feitos baseados na suposição de que o crescimento da escama e o do peixe se fazem numa relação linear.

Tendo-se usado a distribuição dos comprimentos por grupo de anel dos 550 peixes selecionados, cujas escamas mostraram bem os anéis, e mais 19 peixes para o grupo de 0 anel, calculou-se a média de comprimento por anel, para o total de peixes desembarcados, referentes à Tabela $\mathrm{I}$, como se vê na Tabela IXb. Êsses resultados são comparáveis (ver quadro p. 70) com os da Tabela VIII, observando-se que a diferença entre as médias, por grupo de anel, é pequena até 4 anéis; de 5 anéis em diante as diferenças flutuam, o que mostra haver discrepância entre os valôres das duas tabelas, motivado pela dificuldade de identificação dos anéis quando a escama apresenta mais de quatro. Entretanto, levando-se em conta a diferença entre um anel e outro $\left(2 .^{\circ}\right.$ e $1 .^{\circ}, 3 .^{\circ}$ e $2 .^{\circ}$, etc.) de uma mesma tabela, nota-se que há seqüência mais regular entre os valôres da Tabela IXb do que na Tabela VIII, o que permite aceitar tais valôres por ora, considerando-se que são baseados em escamas que permitiram melhor identificação dos anéis.

Os 10.521 peixes medidos foram distribuídos em classes de $1 \mathrm{~cm}$, o que permitiu determinar os valôres modais da curva, com a finalidade de compará-los com os comprimentos médios por grupo de anel. Os valôres dos grupos modais são mostrados no quadro da p. 68, juntos com as médias de comprimentos médios por grupo de anel das Tabelas VIII e IXb. Observa-se que são valôres bem mais próximos aos da Tabela IXb, mostrando correlação entre cada grupo modal e cada grupo de anel. Entretanto, a primeira moda, $20,5 \mathrm{~cm}$, refere-se, como já se tem dito, a peixes selecionados pelos pescadores, refletindo a distribuição de comprimento dos peixes maiores dêsse grupo modal.

Px.
Ex. $\quad$ Peixes examinados

Px. Des. $=$ Peixes desembarcados

* Com correção de meio centímetro

* U Usou-se como chave a distribuição dos comprimentos totais por grupo de anel de 550 peixes utilizados no método do retro-cálculo 


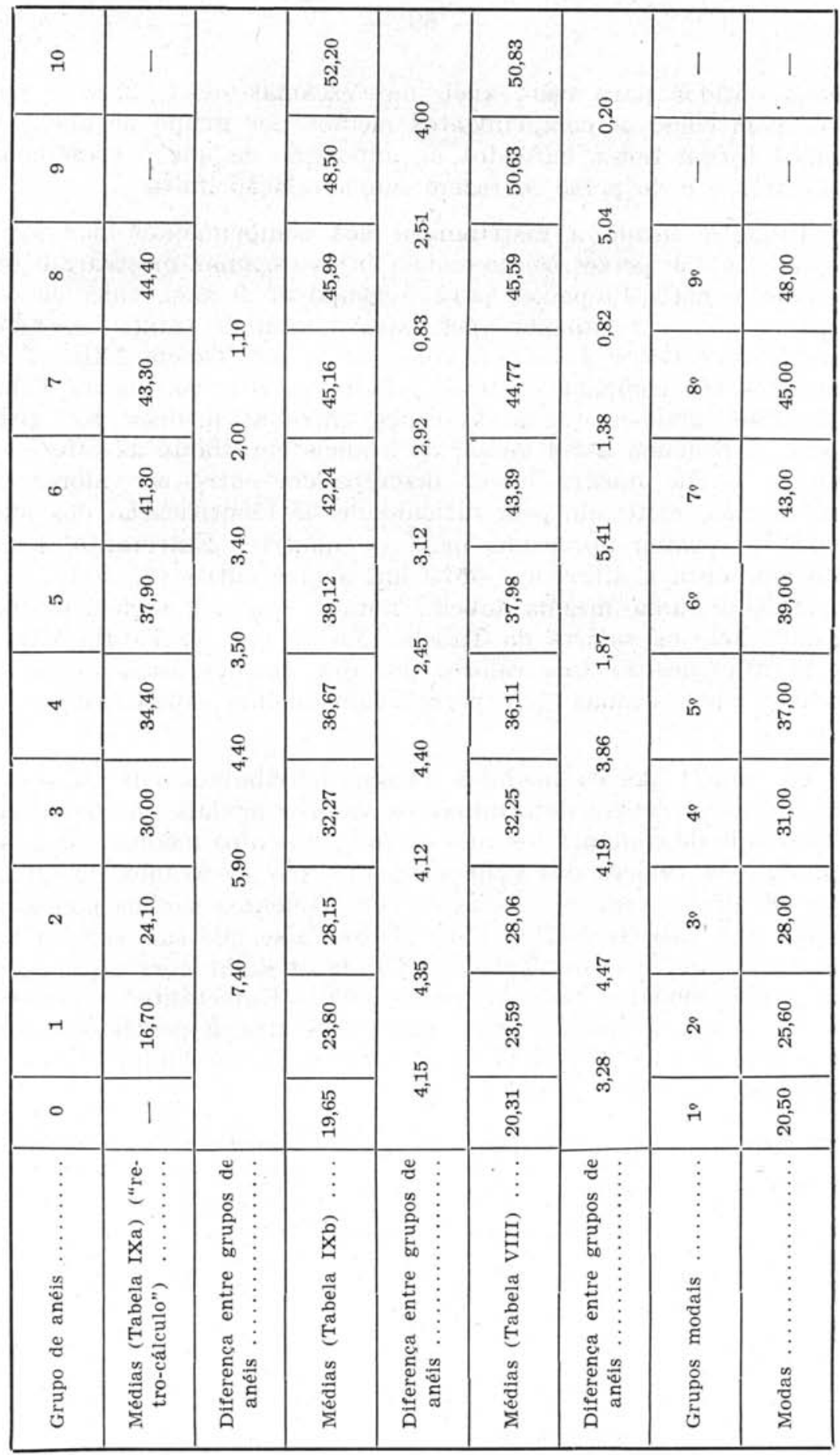


MÉDIAS MENSAIS DE COMPRIMENTOS POR GRUPO DE ANEL - As médias mensais de comprimentos por grupo de anel podem indicar, através de seus valôres máximo e mínimo, se os anéis são formados anualmente ou em outro intervalo de tempo.

Com essa finalidade as médias de comprimentos por grupo de anel, mensais, de 969 peixes, foram calculadas para o período de agôsto de 1958 a agôsto de 1959 (Tabela X).

Os grupos de $0,1,5,6,7,8$ e 9 anéis não apresentam dados em alguns meses; portanto, não foram considerados. Os grupos de 2,3 e 4 anéis apresentam dados mais completos, o que permitiu o traçado da Figura 8, que mostra a tendência das médias mensais, isto é, as médias entre agôsto e novembro não apresentam tendência bem marcada, mas entre dezembro e abril, existe uma tendência bem clara para a queda dos valôres, que voltam a crescer de abril a agôsto para os três grupos.

Êsses resultados mostram, portanto, um período de crescimento acentuado dos peixes, compreendendo, de um modo geral, os meses de abril a agôsto ou talvez até outubro, isto é, meados do outono, todo o inverno e meados da primavera, com a média máxima para cada grupo de anel no período de agôsto a outubro; um período de crescimento pouco acentuado, compreendendo os meses de dezembro a abril, com a média mínima para cada grupo de anel nesse último mês, período êsse que vai de fins da primavera, todo o verão e meados do outono.

Dessa forma os dados analisados mostram que os anéis são anuais, pois durante o período considerado há, para cada grupo de anel, uma média máxima (agôsto) que corresponde à média mínima (abril) do grupo de anel mais avançado. Os anéis parecem ser formados nos meses que precedem abril, meados do verão, por serem êsses os meses que apresentam as médias mais baixas e com pequena variação de seus valôres.

Crescimento - Com a finalidade de se dar representação gráfica ao crescimento da corvina, os dados observados e mostrados na Tabela IXa foram lançados na Figura 9 (círculos brancos), bem como as médias de comprimento total observadas por grupo de anel, das Tabelas VIII e IXb, e os valôres modais da distribuição total de comprimentos na mesma figura. Nota-se que os pontos para os valôres observados seguem a mesma tendência, mostrando em alguns pontos $(0,1,7$ e 8 anéis $)$ ligeiro afastamento devido ao pequeno número de peixes examinados. 


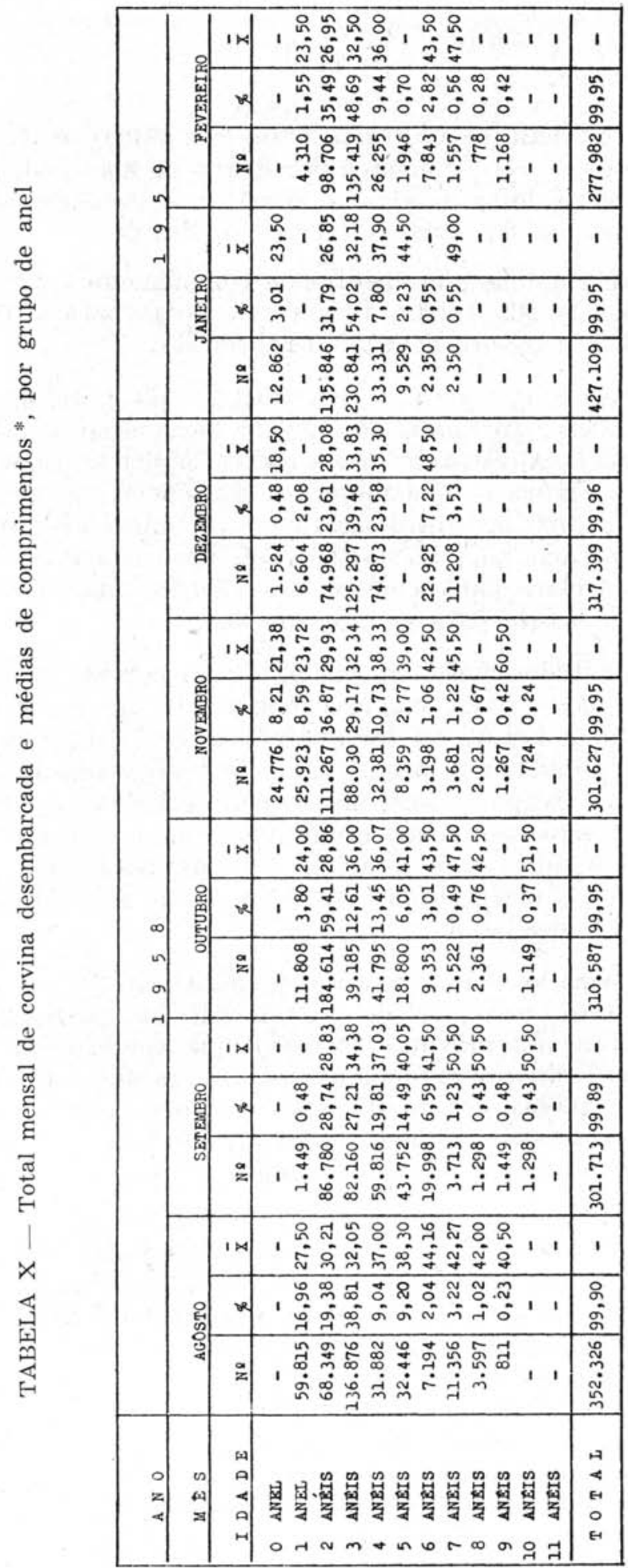




\begin{tabular}{|c|c|c|c|c|}
\hline ส & 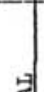 & ef & 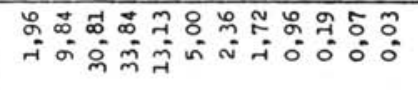 & ूू \\
\hline : & 할 & a & 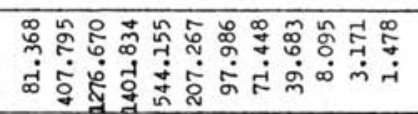 & 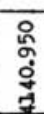 \\
\hline \multirow{18}{*}{ of } & \multirow{3}{*}{ 영 } & 17 & 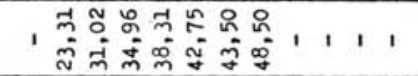 & 1 \\
\hline & & $\Leftrightarrow$ & 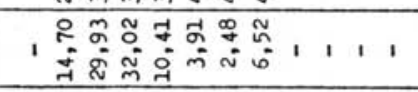 & ตั \\
\hline & & a & 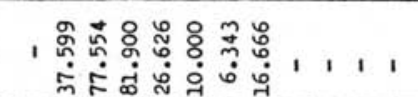 & $\begin{array}{l}\infty \\
: \\
\stackrel{0}{\circ} \\
\dot{x}\end{array}$ \\
\hline & \multirow{3}{*}{ 옇 } & in & 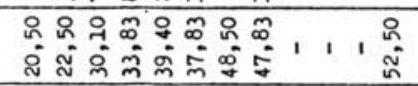 & , \\
\hline & & a & 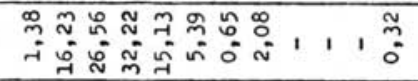 & ू̆ \\
\hline & & $a$ & 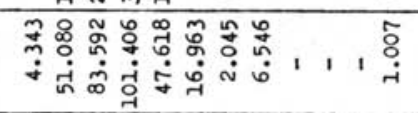 & वृ \\
\hline & \multirow{3}{*}{ 웧 } & $1 x$ & 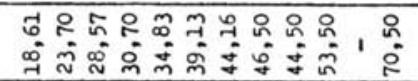 & 1 \\
\hline & & 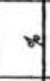 & 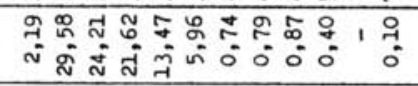 & कू \\
\hline & & $\stackrel{a}{z}$ & 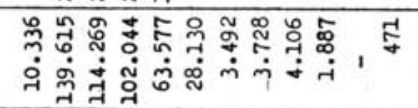 & 点 \\
\hline & \multirow{3}{*}{ 을 } & $1 \times$ & 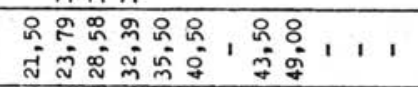 & 1 \\
\hline & & *e & 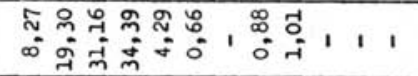 & \%ั \\
\hline & & $a$ & 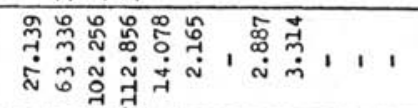 & कृ \\
\hline & \multirow{3}{*}{ 氛 } & $1 \times$ & 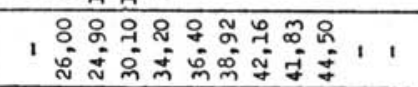 & 1 \\
\hline & & $*$ & 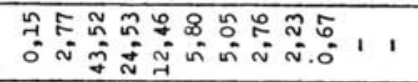 & まे \\
\hline & & $\mathrm{a}$ & 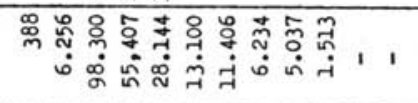 & 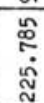 \\
\hline & & $1 \times$ & 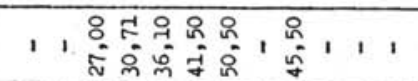 & I \\
\hline & 원 & \& & 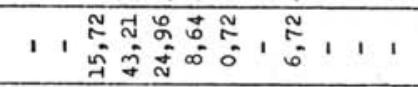 & ลั \\
\hline & & $\mathbf{a}$ & 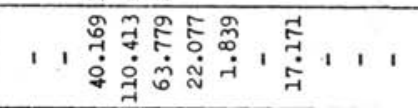 & 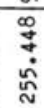 \\
\hline 일 & $\begin{array}{l}\text { (4) } \\
\Rightarrow\end{array}$ & a & 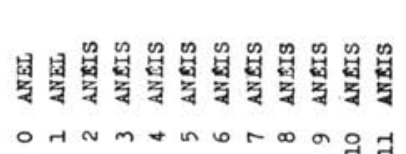 & $\begin{array}{l}H \\
\& \\
\text { H } \\
0 \\
H\end{array}$ \\
\hline
\end{tabular}


Aplicou-se o método de von Bertalanffy para relacionar matemàticamente o comprimento à idade, cuja equação é:

$$
L_{t}=L_{\infty}\left(1-e^{-K\left(t-t_{o}\right)}\right)
$$

onde:

$L_{t}=$ comprimento relativo à idade $t$

$L_{\infty}=$ comprimento (assintótico) quando a idade aumenta indefinidamente

$t \quad=$ idade considerada

$t_{o}=$ idade inicial

$K=$ parâmetro de correlação

$e=$ base dos logarítmos neperianos

Com as médias totais de comprimento "retro-calculadas" por grupo de anel, vistas na Tabela IXa, para um total de 550 peixes, foram calculados os valôres de $L_{\infty}, K$ e $t_{o}$, da equação acima, ficando:

$$
{ }^{7} T=50,7\left(1-e^{-0,25(t+0,59)}\right)
$$

ou

$$
L_{t}=50,7\left(1-e^{-0,25 t-0,14}\right)
$$

com a qual se determinou a curva de crescimento (curva $A$ da Figura 9).

Usando-se as médias de comprimento total por grupo de anel, vistas na Tabela IXb, correspondentes aos peixes usados para o "retro-cálculo", a equação passou a ser:

$$
L_{t}=63,36\left(1-e^{-0,12 t-0,37}\right)
$$

e considerando-se as médias de comprimento por grupo de anel, mostradas na Tabela VIII, a equação tem os seguintes valôres:

$$
L_{t}=62,09\left(1-e^{-0,12 t-0,39}\right)
$$

Como se observa, as duas equações apresentam resultados bem próximos; entretanto, a primeira delas foi usada para a construção da curva $B$ da Figura 9, em vista das médias apresentadas na Tabela IXb serem significativas, como já dissemos mais atrás.

Os valôres modais da distribuição de comprimentos (p. 70), na mesma figura, mostram a mesma tendência da linha de regressão, apresentando, em alguns pontos $(0,1,7$ e 8 anéis), ligeiro afastamento devido ao pequeno número de peixes examina- 
dos. A correspondência dos diferentes valôres modais com as médias para cada grupo de anel se faz da seguinte maneira: a $1^{\text {t }}$ moda corresponde ao grupo de 0 anel; a $2^{a}$ moda, ao grupo de 1 anel, e assim por diante.

As duas curvas ( $A$ e $B$ ) mostram a mesma tendência a partir do $4 .^{\circ}$ anel, mantendo-se igual a distância entre elas, enquanto que para o $10^{\circ}, 2 .^{\circ}$ e $3 .^{\circ}$ anéis a distância entre os pontos correspondentes nas duas curvas é grande, acentuadamente para 0 1. anel, diminuindo gradativamente até o $3 .^{\circ}$ anel.

Como já ficou dito, considerando-se o comprimento total do peixe, correspondente à distância entre o foco e o bordo da escama, entende-se ser a distância entre as duas curvas motivada pelo crescimento do peixe antes da formação da escama e depois da formação do último anel, isto é, a distância que vai do último anel ao bordo da escama. Essa distância se acentua ainda mais para os dois primeiros anéis $\left(0\right.$ e $\left.1 .^{\circ}\right)$ devido à seleção dos peixes dêsses grupos efetuada pelos pescadores, o que acarreta distribuição de comprimentos referentes aos peixes de maior porte por grupo de anel.

Considerando-se a seleção efetuada com os peixes de 0 e 1 anel e o pequeno número de peixes examinados para os grupos de 6, 7 e 8 anéis, recalculou-se a curva de crescimento (curva $B$ ), com base nos valôres dos grupos de 2, 3, 4 e 5 anéis da Tabela IXb, por serem representativos. Dessa forma, obteve-se a curva $C$, cuja equação é:

$$
L_{t}=52,61\left(1-e^{-0,20 t-0,37}\right)
$$

onde a seleção de peixes e o vício na amostragem, já assinalados, ficam atenuados, o que leva à maior aproximação das médias por grupo de anel e comparação com os valôres "retro-calculados".

A seguir são apresentados os valôres, em centímetros, da distância entre dois pontos correspondentes, valôres êsses que indicam a diferença entre a média obtida por "retro-cálculo" (Tabela IXa) e a média obtida com o comprimento total do peixe (Tabela IXb), tendo sido calculados os valôres porcentuais dessas diferenças:

\begin{tabular}{|c|c|c|c|c|c|c|c|c|}
\hline Anel & 1 & 2 & 3 & 4 & 5 & 6 & 7 & 8 \\
\hline $\mathrm{cm}$ & 7,1 & 4,0 & 2,3 & 2,3 & 1,2 & 0,9 & 1,8 & 1,6 \\
\hline$\%$ & 42,46 & 16,60 & 7,66 & 6,70 & 3,16 & 2,18 & 4,14 & 3,60 \\
\hline
\end{tabular}


Êsses valôres devem ser observados levando-se em conta o número de peixes examinados por grupo de anel. Outra maneira de se obter a diferença entre os pontos correspondentes das duas curvas é substituir, nas equações de crescimento que expressam as curvas $A$ e $B$ da Figura 9 , os valôres de $t$, isto é, as diferentes idades (ou grupos de anéis).

Pode-se verificar que os três primeiros grupos são os que apresentam valôres bem acima da curva de "retro-cálculo" (curva $A$ ), e isso é devido ao pequeno número de peixes examinados mais a seleção efetuada pelos pescadores e pela malhagem das rêdes.

Considerando-se as médias da Tabela IXa foi calculado o incremento no crescimento entre um grupo de anel e outro, em centímetros, tendo sido calculados, também, os valôres porcentuais correspondentes, como segue:

\begin{tabular}{|c|c|c|c|c|c|c|c|}
\hline Anel & $2-1$ & $3-2$ & $4-3$ & $5-4$ & $6-5$ & $7-6$ & $8-7$ \\
\hline $\mathrm{cm}$ & 7,4 & 5,9 & 4,4 & 3,5 & 3,4 & 2,0 & 1,1 \\
\hline$\%$ & 44,31 & 24,48 & 14,66 & 10,17 & 8,97 & 4,84 & 2,54 \\
\hline
\end{tabular}

DISTRIBUIÇÃO DAS IDADES PARA O TOTAL DESEMBARCADO - O conhecimento da composição da idade dos peixes desembarcados permite, em anos sucessivos, determinar suas variações periódicas, a taxa de mortalidade por pesca para cada classe de idade, bem como o grau em que é feita a seleção por parte dos pescadores.

Com êsse objetivo foi usada a chave idade-comprimento das amostras mensais, para a obtenção do número total mensal de peixes desembarcados por classe de comprimento, assim como a sua distribuição por grupo de anel. Com êsses dados foram elaboradas as Tabelas X e XI, referentes à corvina e à corvina englobada na mistura.

A Tabela X abrange o período de agôsto de 1958 a agôsto de 1959 , com um total de 4.142 .216 peixes, enquanto que a Tabela XI abrange o período de novembro de 1958 a agôsto de 1959, com exclusão de janeiro e fevereiro de 1959, por não terem sido obtidos dados, com um total de 616.150 peixes.

A Figura 10 mostra o histograma de distribuição, em número, por grupo de anel, para todo o período estudado, para a corvina e corvina englobada na mistura. Os valôres são vistos na última coluna das Tabelas X e XI. 


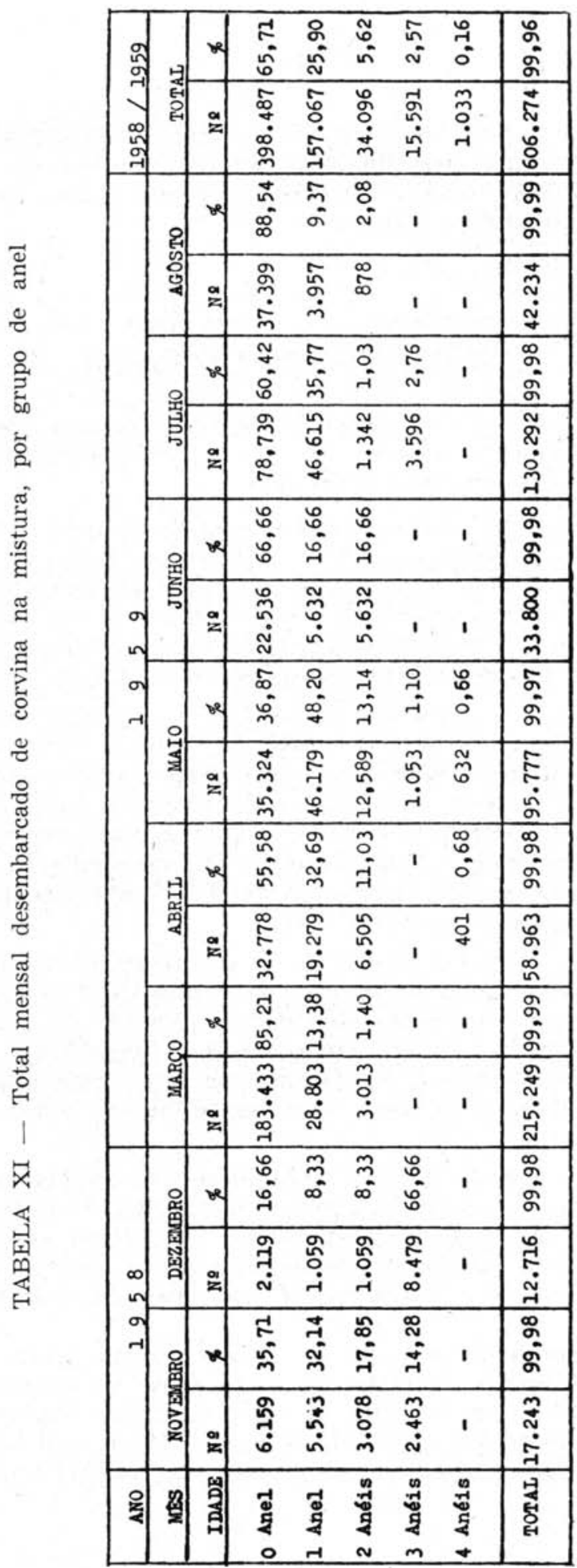


Pela figura observa-se que na corvina da mistura predominou a classe de 0 anel, com 398.487 peixes, seguida da classe de 1 anel, com 157.067 peixes. As demais classes apareceram com freqüências relativamente baixas.

Para a corvina observa-se que a classe de 0 anel apresenta freqüência relativamente baixa, enquanto que para as classes de $1,2,3$ e 4 anéis as freqüências foram altas. As demais classes apresentaram freqüências baixas, decrescentes de classe para classe.

Assim, vê-se que no desembarque de corvina durante o período considerado, as classes de 2 e 3 anéis predominaram com freqüências aproximadamente iguais.

Com os valôres porcentuais mensais da Tabela $\mathrm{X}$ foi construída a Figura 11 que mostra, em intervalos de $10 \%$, os histogramas das freqüências mensais do total de corvinas desembarcadas por grupo de anel. Na figura não foram incluídos os valôres da Tabela XI, referentes à corvina englobada na mistura, por terem os mesmos representação pouco significativa em quase todos os meses.

Na Figura 11, para as classes de 0 e 1 anel, distinguem-se dois períodos: um, que vai de agôsto de 1958 a fevereiro de 1959 , onde as porcentagens para as duas classes são baixas; outro, que vai de abril a agôsto de 1959, onde a classe de 0 anel mostra porcentagens decrescentes e a de 1 anel é mais representada que no primeiro período. Pela Tabela XI, referente à corvina da mistura, observa-se que as classes de 0 e 1 anel mostram-se mais representativas nesse período.

As classes de 2 e 3 anéis são mais freqüentes, com predominância em quase todos os meses, da classe de 3 anéis. A classe de 4 anéis mostra oscilação em sua freqüência, de mês para mês, sendo que a mesma, de um modo geral, é mais baixa que as das classes de 2 e 3 anéis. As classes de 5 e mais anéis mostram freqüências baixas, não sendo representadas em todos os meses.

PÊSo - O estudo do pêso está ligado ao conhecimento de sua variação durante o desenvolvimento do peixe, bem como permite determinar o seu pêso correspondente ao ótimo econômicamente capturável. Para tanto, torna-se necessário conhecer a relação comprimento-pêso e o crescimento em pêso da corvina.

Relação comprimento-pêso - Dessa forma, para se obter as informações sôbre a variação do pêso para as diferentes classes de comprimentos da corvina, foram coletados dados sôbre 359 peixes, que podem ser vistos na Tabela XII, a qual mostra a distribuição dos pesos médios por classe de comprimento, lançados na Figura 12. 
TABELA XII — Perímetro médio e pêso médio, por cornprimento (corvina).

\begin{tabular}{|c|c|c|c|c|}
\hline \multirow{2}{*}{$\begin{array}{l}\text { Comprimento } \\
\qquad(\mathrm{cm})^{*}\end{array}$} & \multicolumn{2}{|c|}{ PERIMETRO } & \multicolumn{2}{|c|}{ PÊSO } \\
\hline & No de peixes & $\begin{array}{l}\text { Perimetro } \\
\text { médio }(\mathrm{cm})^{*}\end{array}$ & No de peixes & $\begin{array}{l}\text { Pêso médio } \\
\text { (g) }\end{array}$ \\
\hline 13,5 & - & - & 1 & 20,00 \\
\hline 14,5 & - & 一 & 1 & 25,00 \\
\hline 15,5 & - & - & - & - \\
\hline 16,5 & 3 & 10,83 & 3 & 41,66 \\
\hline 17,5 & 6 & 9,86 & 5 & 54,00 \\
\hline 18,5 & 6 & 10,50 & 3 & 58,33 \\
\hline 19,5 & 17 & 11,08 & 4 & 75,00 \\
\hline 20,5 & 26 & 11,61 & 15 & 82,33 \\
\hline 21,5 & 32 & 12,28 & 13 & 94,61 \\
\hline 22,5 & 37 & 12,93 & 12 & 115,00 \\
\hline 23,5 & 55 & 13,88 & 23 & 139,34 \\
\hline 24,5 & 53 & 14,53 & 15 & 144,33 \\
\hline 25,5 & 58 & 15,55 & 17 & 172,05 \\
\hline 26,5 & 52 & 15,73 & 18 & 179,72 \\
\hline 27,5 & 76 & 15,89 & 28 & 215,35 \\
\hline 28,5 & 73 & 16,56 & 21 & 230,47 \\
\hline 29,5 & 75 & 17,26 & 18 & 266,38 \\
\hline 30,5 & 75 & 18,11 & 22 & 294,54 \\
\hline 31,5 & 70 & 18,83 & 19 & 328,15 \\
\hline 32,5 & 77 & 19,37 & 20 & 360,50 \\
\hline 33,5 & 60 & 19,63 & 16 & 382,81 \\
\hline 34,5 & 64 & 20,96 & 15 & 434,33 \\
\hline 35,5 & 56 & 21,19 & 15 & 462,66 \\
\hline 36,5 & 50 & 21,86 & 10 & 483,00 \\
\hline 37,5 & 48 & 22,16 & 7 & 560,71 \\
\hline 38,5 & 42 & 22,64 & 8 & 615,62 \\
\hline 39,5 & 45 & 23,12 & 7 & 642,14 \\
\hline 40,5 & 31 & 24,30 & 3 & 660,00 \\
\hline 41,5 & 31 & 24,69 & 3 & 738,33 \\
\hline 42,5 & 28 & 25,42 & 4 & 796,25 \\
\hline 43,5 & 26 & 25,65 & 2 & 867,50 \\
\hline 44,5 & 16 & 26,75 & 2 & 952,50 \\
\hline 45,5 & 19 & 26,81 & 2 & 892,50 \\
\hline 46,5 & 12 & 28,75 & 1 & $1.075,00$ \\
\hline 47,5 & 10 & 29,40 & - & - \\
\hline 48,5 & 8 & 28,37 & 2 & $1.150,00$ \\
\hline 49,5 & 2 & 30,50 & - & - \\
\hline 50,5 & 10 & 30,60 & - & - \\
\hline 51,5 & 10 & 31,10 & 2 & $1.395,00$ \\
\hline 52,5 & 5 & 32,50 & 1 & $1.400,00$ \\
\hline 53,5 & 4 & 35,00 & - & - \\
\hline 54,5 & 4 & 32,75 & - & - \\
\hline 55,5 & 5 & 33,10 & - & 一 \\
\hline 56,5 & 1 & 32,50 & - & 一 \\
\hline 57,5 & 1 & 37,50 & 一 & - \\
\hline 58,5 & - & - & - & - \\
\hline 59,5 & - & - & 7 & $\overline{2} \overline{0}$ \\
\hline $\begin{array}{l}60,5 \\
61,5\end{array}$ & 1 & 31,50 & 1 & $2.200,00$ \\
\hline 62,5 & 二 & - & - & 二 \\
\hline 63,5 & - & - & - & - \\
\hline 64,5 & 1 & 36,50 & - & - \\
\hline 65,5 & 1 & 37,50 & - & - \\
\hline Total ........ & 1.382 & - & 359 & - \\
\hline
\end{tabular}

- Com correção de mais $0,50 \mathrm{~cm}$. 
O pêso do corpo de um peixe é proporcional ao cubo do comprimento, o que indica ser alométrica a relação comprimento-pêso. Essa relação tem sido expressa recentemente pela equação:

$$
W=k L^{x}
$$

onde $W$ é o pêso, $L$ é o comprimento, $k$ e $x$ são os parâmetros característicos da espécie, cujos valôres foram determinados através da reta de regressão dos logarítmos de $W$ e $L$ vistos na Tabela XII, excluindo-se as classes com menos de dez peixes, ficando, portanto:

$$
W=0,008 L^{3,12}
$$

Nota-se que todos os valôres observados, apresentados na Tabela XII e lançados na Figura 12, mostram desvios, com relação à curva calculada, a partir de $45,5 \mathrm{~cm}$, devido ao pequeno número de peixes examinados.

Crescimento em pêso - Para se estudar o crescimento em pêso da corvina foram coletados dados, constantes da Tabela XIII, onde se observa o pêso médio por grupo de anel. Êsses dados foram lançados na Figura 13. Sendo poucos os dados observados e talvez não representativos para o período estudado, achou-se melhor, com base nesses dados, calcular a curva de crescimento.

TABELA XIII - Distribuição de perimetros médios e pesos médios por

\begin{tabular}{|c|c|c|c|c|c|}
\hline \multirow{2}{*}{ Anéis } & \multirow{2}{*}{ (idade) } & \multicolumn{2}{|c|}{ PERIMETRO } & \multicolumn{2}{|c|}{ PESO } \\
\hline & & No de peixes & $\begin{array}{c}\text { Perimetro } \\
\text { médio * }\end{array}$ & No de peixes & $\begin{array}{l}\text { Pêso médio } \\
(\mathrm{g})\end{array}$ \\
\hline & 0 & 23 & 12,08 & 13 & 99,23 \\
\hline & 1 & 73 & 13,82 & 21 & 148,80 \\
\hline & 2 & 145 & 17,00 & 51 & 228,03 \\
\hline & 3 & 171 & 19,40 & 42 & 352,61 \\
\hline & 4 & 89 & 22,51 & 21 & 552,38 \\
\hline & 5 & 37 & 23,51 & 7 & 665,71 \\
\hline & 6 & 17 & 26,94 & 3 & 786,66 \\
\hline & 7 & 14 & 27,00 & 2 & $1.282,50$ \\
\hline & 8 & 8 & 26,81 & 1 & $1.380,00$ \\
\hline & 9 & 4 & 32,87 & 1 & $2.200,00$ \\
\hline & 10 & 一 & - & 一 & 一 \\
\hline & 11 & 1 & 33,00 & - & 一 \\
\hline Total & $\ldots \ldots$ & 582 & 一 & 162 & - \\
\hline
\end{tabular}
grupo de idade

* Expresso em cm, com correção de $+0,50 \mathrm{~cm}$. 
Assim, da equação que expressa o crescimento do comprimento em relação à idade:

$$
L_{t}=63,36\left(1-e^{-0,12 t-0,37}\right)
$$

e da equação que expressa a relação comprimento-pêso:

$$
W=0,008 L^{3,12}
$$

obtém-se a equação:

$$
W=3.304,8\left(1-e^{-0,12 t-0,37}\right)^{3,12}
$$

que define a curva de crescimento do pêso em função dos grupos de anéis (idades), o que é representado pela curva da Figura 13.

Os desvios que se notam entre os valôres observados e a curva calculada são devidos ao pequeno número de peixes examinados (162) e a curva é resultante de duas expressões, cujos coeficientes foram calculados com base em maior número de peixes.

PERÍmetro - $\mathrm{O}$ estudo do perímetro em relação ao comprimento e à idade é importante porque está ligado aos problemas da seleção de peixes através das malhas das rêdes de pesca. Êsses trabalhos estão em andamento, sendo que parte dêles se encontra no prelo (Moreira).

Relação comprimento-perímetro - Para o estudo da relação comprimento-perímetro foram coletados dados sôbre 1.382 peixes, cujos resultados são vistos na Tabela XII e foram lançados na Figura 14.

Como mostra a distribuição dos pontos observados na figura, a relação comprimento-perímetro é linear e pode ser expressa pela equação:

$$
P=k^{\prime} L+a
$$

onde $P$ é o perímetro, $k^{\prime}$ e $a$ são os parâmetros característicos da espécie, e $L$ é o comprimento.

Com base nos dados da Tabela XII e não considerando as classes com menos de dez peixes, foram calculados os valôres de $k^{\prime}$ e $a$ da equação dada, através de regressão, ficando, portanto:

$$
P=0,62 L-1,00
$$

que expressa a linha traçada na Figura 14. 
Nota-se que os desvios entre os pontos observados e a linha traçada são pequenos para os valôres compreendidos entre 17,5 e $51,5 \mathrm{~cm}$ para comprimento. Para os pontos correspondentes a 16,5 e $52,5 \mathrm{~cm}$ em diante o número de peixes é pequeno, acarretando desvios grandes que, por ora, impossibilitam aceitar os dados como sendo representativos da relação em estudo.

Crescimento em perímetro - Foram determinados os perímetros médios para os diferentes grupos de anéis, cujos valôres são mostrados na Tabela XIII e foram lançados na Figura 15.

Para se calcular a curva de crescimento do perímetro foram usadas as equações:

$$
L_{t}=63,36\left(1-e^{-0,12 t-0,37}\right)
$$

e

$$
P=0,62 L-1,00
$$

que, por substituição, dão a equação:

$$
P=39,28\left(1-e^{-0,12 t-0,37}\right)-1,00
$$

que expressa a curva vista na Figura 15.

Os desvios observados entre os valôres para cada grupo de anel e os valôres correspondentes da curva calculada são relativamente pequenos, com exceção das classes de 8 e 9 anéis, devido ao número pequeno de peixes examinados (não há dados para a classe de 10 anéis).

Relação perímetro-pêso - Para a relação perímetro-pêso foram feitas observações, cujos resultados são vistos na Tabela XIV e foram lançados na Figura 16.

Considerando-se as equações:

$$
W=k L^{x}
$$

$\mathrm{e}$

$$
P=k^{\prime} L+a
$$

obtém-se

$$
W=k\left(\frac{P-a}{k^{\prime}}\right)^{x}
$$

que expressa a relação alométrica entre perímetro e pêso médio. 
Os valôres de $k, k^{\prime}$ e $x$ já foram determinados; dessa forma tem-se :

$$
W=0,008\left(\frac{P+1,00}{0,62}\right)^{3,12}
$$

Determinando-se os diferentes valôres de $W$ para os diferentes perímetros (Tabela XIV) tem-se os pontos que, lançados na Figura 16, determinam a curva que expressa a relação logarítmica.

TABELA XIV — Distribuição do pêso médio por classe de perimetro

\begin{tabular}{|c|c|c|}
\hline Perímetro $(\mathrm{cm})$ & No de peixes & Pêso médio \\
\hline 9,5 & 4 & 61,25 \\
\hline 10,5 & 6 & 73,33 \\
\hline 11,5 & 17 & 87,94 \\
\hline 12,5 & 18 & 109,44 \\
\hline 13,5 & 26 & 147,69 \\
\hline 14,5 & 29 & 168,62 \\
\hline 15,5 & 30 & 204,50 \\
\hline 16,5 & 35 & 252,57 \\
\hline 17,5 & 26 & 290,76 \\
\hline 18,5 & 41 & 345,36 \\
\hline 19,5 & 21 & 390,71 \\
\hline 20,5 & 20 & 455,75 \\
\hline 21,5 & 16 & 518,12 \\
\hline 22,5 & 10 & 608,50 \\
\hline 23,5 & 5 & 643,00 \\
\hline 24,5 & 6 & 744,16 \\
\hline 25,5 & 6 & 827,50 \\
\hline 26,5 & 3 & 890,00 \\
\hline 27,5 & 1 & $1.135,00$ \\
\hline 28,5 & 一 & - \\
\hline 29,5 & 1 & $1.400,00$ \\
\hline 30,5 & 1 & $1.410,00$ \\
\hline 31,5 & 1 & $2.200,00$ \\
\hline Total .... & 323 & - \\
\hline
\end{tabular}

Os desvios entre os valôres observados e a curva são relativamente pequenos. Apenas no extremo direito da curva os desvios são grandes devido ao pequeno número de peixes examinados. 
Os dados estudados neste trabalho foram coletados desde agôsto de 1958 até agôsto de 1959, e provieram da área compreendida entre os paralelos $23^{\circ} \mathrm{S}$ e $34^{\circ} \mathrm{S}$, para uma faixa de poucas milhas distante da costa brasileira.

A distribuição dos comprimentos para o total de 10.521 peixes medidos no Entreposto de Pesca de Santos, durante o periodo já referido, mostrou um valor modal de $30,4 \mathrm{~cm}$, e os limites de comprimentos foram de 16 até $70 \mathrm{~cm}$. A mistura (categoria comercial que inclui várias espécies, englobando corvinas pequenas), representa $12,93 \%$ do total em número da corvina desembarcada, com valor modal de $20,4 \mathrm{~cm}$, tendo por limites de comprimento 12 e $38 \mathrm{~cm}$ (distribuição viciada).

Tanto as médias mensais de comprimentos, como os valôres modais das curvas mensais de distribuição dos comprimentos mostram que a corvina cresce no periodo compreendido entre o outono e parte do inverno. No inicio do período aparece um valor modal baixo, correspondendo a uma queda brusca das médias mensais de comprimento, sugerindo que peixes de pequeno tamanho são recrutados para a pesca nessa época.

O exame das escamas mostrou a existência de marcas, que possibilitaram a determinação da idade.

Supondo-se que o crescimento das escamas e do peixe se faz obedecendo a uma relação linear, usou-se os métodos do "retro-cálculo" e de von Bertalanffy para a construção da curva de crescimento.

Através das médias mensais de comprimento por grupo de anel determinou-se a periodicidade da formação do anel, que é anual, correspondendo a meados do verão até meados do outono, portanto, antes de abril, mês em que as médias de comprimentos possuem valôres baixos.

Para o total de corvinas desembarcadas verificou-se serem as classes de 2 e 3 anéis as que predominaram, com percentagens altas, seguidas das classes de 1 e 4 anéis. Na distribuição mensal observou-se que as classes de 2 e 3 anéis predominaram, alternando suas freqüências em alguns meses e que a partir do mês de abril de 1959 as classes de 0 e 1 anel são mais regulares e mostram percentagens relativamente altas.

As relações comprimento-pêso, comprimento-perimetro, pêso-perímetro e o crescimento do pêso $\mathrm{e}$ do perímetro foram tratadas matemàticamente, tendo-se calculado os coeficientes de correlação das equaçōes correspondentes.

\section{VI - SUMMARY}

The purpose of this paper is to present the first results obtained on the length/frequency distribution, age and growth, and the relations length/weight, length/girth, and girth/weight, of Corvina (Micropogon furnieri $=$ M. opercularis), a fish of the family Sciaenidae caught off the Brazilian coast.

This work is part of a long term programme designed to assess the size of the fishable stocks, to suggest the proper management of these stocks, and to aid the fishing industry in their rational exploitation.

The data were obtained at the fish market of Santos in the period from August 1958 to August 1959. They were obtained from an area which extends between the parallels $23^{\circ} \mathrm{S}$ and $34^{\circ} \mathrm{S}$ and a few miles off the Brazilian coast; the area exploited by the Santos fishing fleet (Fig. 1). 
The data, however, are insufficient to define all the biological parameters of the fish under consideration. Nevertheless, they are a beginning towards assessment of the marine resources of Brazil.

The author does not try to draw final conclusions, but only to present the first results of the research under way.

Corvina is landed at the fish market in two forms: 1) Corvina as such, and sold under that name, and this comprises the bulk of the landing; and 2) Corvina included in "mistura" (a market category composed of a number of different species). These fish are of a small size and may be up to $12.93 \%$ of the total landed by numbers.

The Corvina landed as "mistura" suffers from a selection made by the fishermen and therefore it was difficult to obtain good sampling of the numbers of Corvina landed of the lower lenghts. For this reason little use has been made of the data referring to Corvina landed as "mistura".

For the period of thirteen months the length range was from 16 to 70 $\mathrm{cm}$, with a modal value of $30.4 \mathrm{~cm}$ for corvina. For corvina included in "mistura" the range was 12 to $38 \mathrm{~cm}$, with a modal value of $20.4 \mathrm{~cm}$ (Tables IV and V, and Fig. 2).

The monthly length distributions (Table IV and Fig. 3) show the main modal values shifting to the right. This shifting is more visible from April to August. From March on, the curves show two clear modes; they also show a class of small fish, with low modal values. By examining the values of Table V it can be seen that small fish included in "mistura" appear in the catches in great quantity at that period.

The monthly mean lengths (Table VI and Fig. 4) fluctuate from month to month, in the period from the end of winter, spring and almost all summer (Southern Hemisphere), but there is an overall trend towards a lower mean length during this period. It is suggested that this period is a period of reduced growth.

In the period which includes all autumn and part of the winter months the mean lengths show, at the beginning of the period, a sharp fall followed by rapid increase, and this is the period of growth. This, together with the results from the modal values, suggests that in March small fish are recruited to the fishery.

The modal values in Table $\mathrm{V}$ show that the period of growth is from the end of summer through autumn and part of winter, or from the end of March until August, a similar result is obtained using mean length values.

The examination of scales showed rings (Fig. 6) which, it was thought, could be used for age determination. After two independent readings of the scales of the corvina samples and the corvina included in "mistura", the mean length per group of rings and the standard error of the mean for each group was calculated (Tables VII and VIII). The standard error was low for all groups with 0 to 5 rings.

The method of back calculation was used and the assumption made that the relation between scale size and total length was linear. No correaction factor was applied. Using these data a growth curve (Fig. 9, curve A) was constructed and von Bertalanffy's formula was used to express the results.

$$
L_{t}=50.7\left(1-e^{-0.25 t-0.14}\right)
$$

It can be seen that there is rapid growth until the 3rd ring after which growth is less marked. 
Using the mean length per ring group (Tables VIII and IXb) and the modal values from the length distribution of all fish (p. 74) growth curves were also drawn (Fig. 9, curve B) and the equation of von Bertalanffy applied. In this manner two sets of curves were obtained. Curve $A$ is based on the size of the fish at the formation of the ring (without correction for non linearity in the scale/length relationship) and curve $B$ based on the total length for each ring group. The modal lengths are similar to the mean lengths per ring group and it can therefore be assumed that the modes represent ring groups or age groups.

The mean lengths per ring group (Table $\mathrm{X}$ ) for each month are shown in Figure 8 for the 2, 3 and 4 ring groups. It can be seen that there appears to be only one maximum and minimum during the period August to October of the following year, and the maximum in one group approximates to the minimum in the following group. The minimum occurs in April. The rings are therefore assumed to be formed annually sometime before April, in summer or beginning of autumn.

Using the age sampling in the form of an age/length key, together with the total number of fish of each length landed, the number of fish at each age was calculated (Tables X and XI, and Fig. 10). It can be seen that the fish landed as "mistura" belong to the 0 ring group. The dominant ring group are the 2 and 3 ring group and after these the fish with 1 or 4 rings on the scales.

The monthly age distribution (Fig. 11) shows one period when the 2 and 3 ring group predominate, either one or the other being dominant. This lasts from August 1958 to March 1959. The other period from April to August 1959 has a higher frequency of fish with 0 and 1 ring on the scale. This later period is the period of recruitment into the fishery. The same can be seen from the data taken from "mistura" (Table XI).

The equations used to express the relation between age and weight, age and girth of the fish, length and weight, length and girth, and girth and weight are as follows:

Age/weight: $\quad W=3,304.8\left(1-e^{-0.12 t-0.37}\right)^{3.12}$

(Fig. 12)

Age/girth: $\quad P=39.28\left(1-e^{-0.12 t-0.37}\right)-1.00$

(Fig. 13)

Length/weight: $\quad W=0.008 L^{3.12}$

(Fig. 14)

Length/girth: $\quad P=0.62 L-1.00$

(Fig. 15)

Girth/weight : $\quad W=0.008\left(\frac{P+1.00}{0.62}\right)^{3.12}$

(Fig. 16)

\section{VII - AGRADECIMENTOS}

$\mathrm{O}$ autor agradece a orientação recebida de $\mathrm{Mr}$. Ian Dennis Richardson, técnico da "Food and Agriculture Organization of the United Nations" (FAO) e a todos os elementos do Grupo de Pesquisas sôbre a Pesca Marítima, que colaboraram na execução dêste trabalho. 


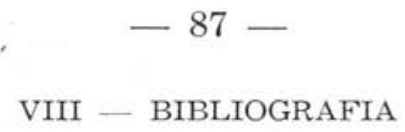

Barcellos, B. N. \& Richardson, I. D.

1960. Carta pesqueira do Rio Grande do Sul (estudos): Pesquisas sôbre a pesca do alto mar em Rio Grande. Pôrto Alegre, Secretaria da Agricultura, 17 p., 3 tabs., 6 figs.

Braga, A. S.

1962. Compilação e computação de dados estatísticos de desembarque de pescado no pôrto de Santos. Bol. Inst. Ocean., vol. XII, n. ${ }^{\circ} 2$.

LARA, F. J. S.

1951. A study of the life history of Macrodon ancylodon (Bloch \& Schneider), a sciaenid fish occurring on the coast of Southern Brazil. An. Acad. Bras. Cien., vol. 23, n. ${ }^{\circ}$ 3, p. 291-322.

MOREIRA, P. S.

Quantidade dos peixes rejeitados pela frota comercial de Santos e observações sôbre a seletividade das malhas de $54 \mathrm{~mm}$. (Em preparação).

Richardson, I. D. \& Moraes, M. M.

1960. A first appraisal of the landing and mechanism of the Santos fishery. Bol. Inst. Ocean., vol. XI, n. ${ }^{\circ} 1$, p. 5-86.

Richardson, I. D. et al.

1959. Report on sardine investigations in Brazil. Rome, FAO, v+7 p., 5 tabs., 7 figs. (Experience paper, n. ${ }^{\circ} 13$ ). 


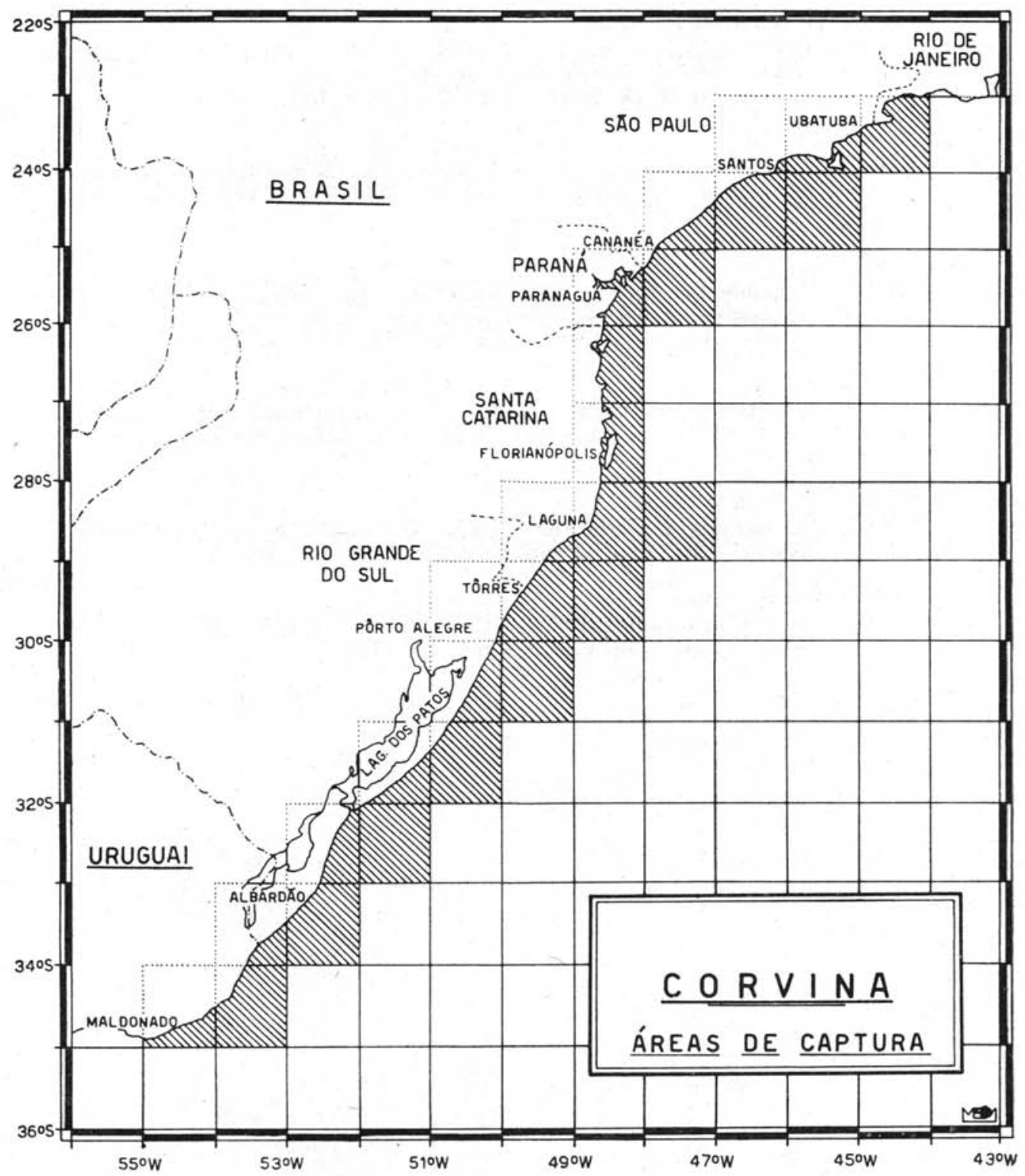

Fig. 1 - Áreas de captura da corvina, compreendendo desde o paralelo $23^{\circ} \mathrm{S}$ até o paralelo $34 \%$, numa faixa ao longo da costa. 


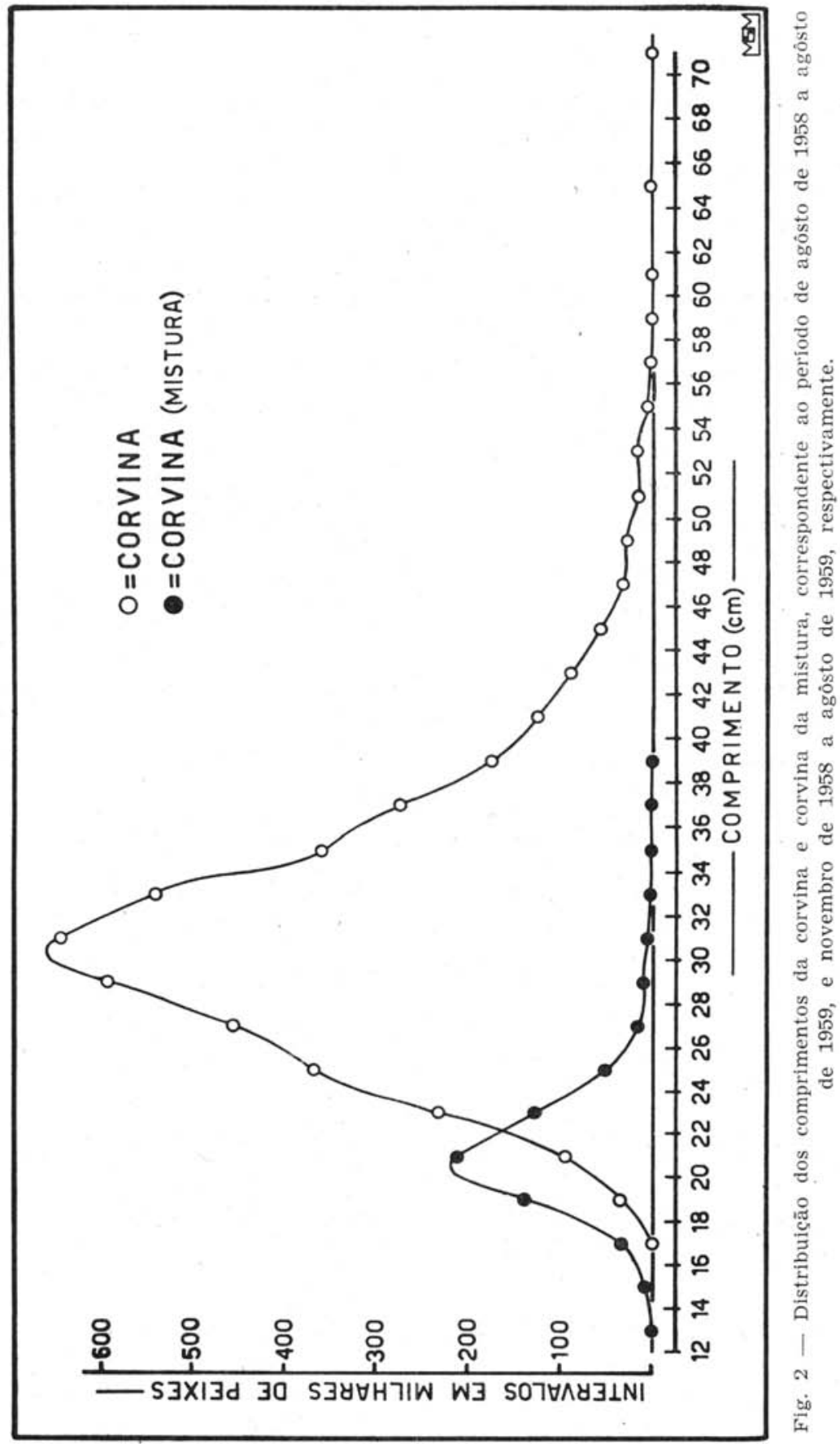




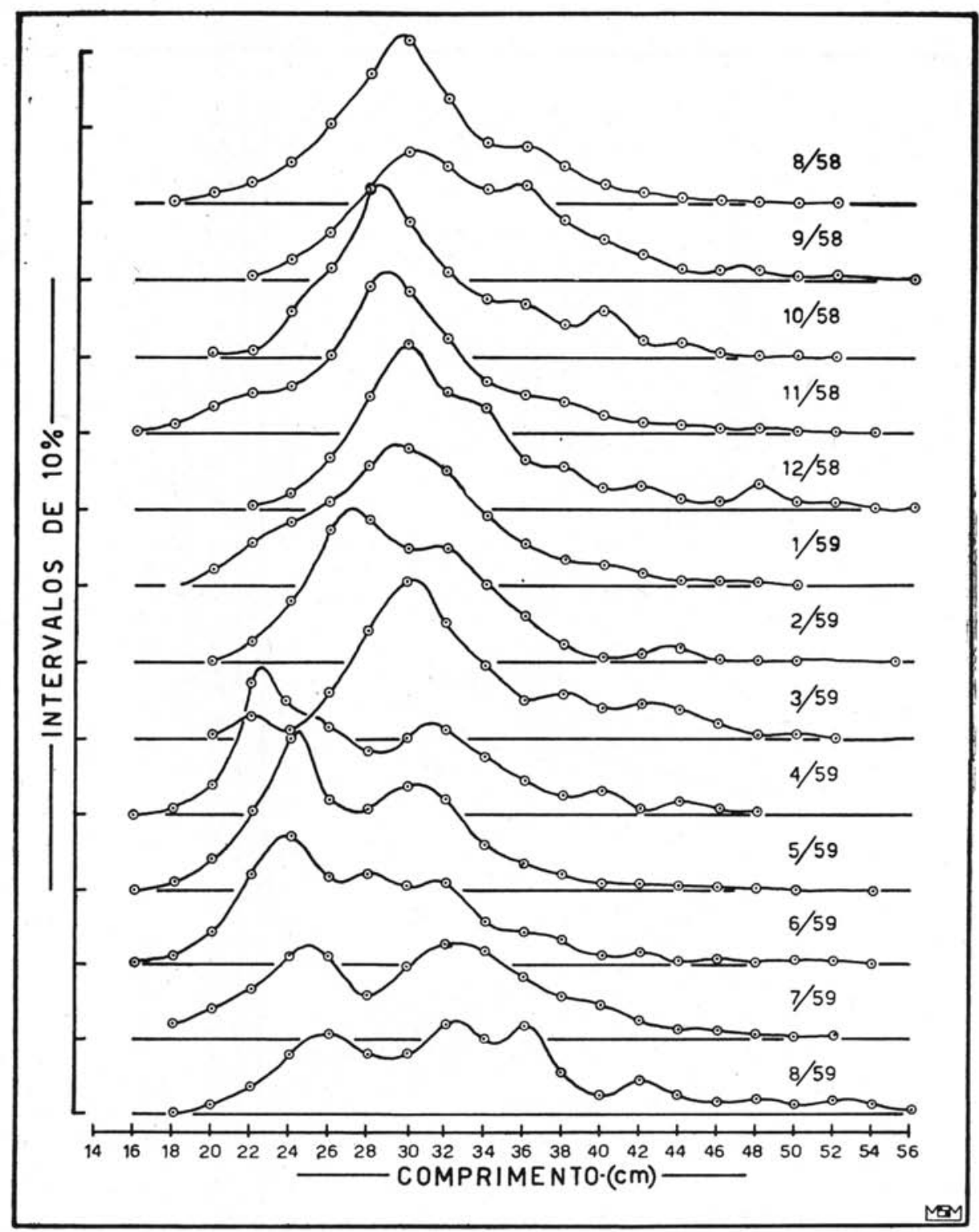

Fig. 3 - Distribuiçăo porcentual mensal dos comprimentos da corvina. 


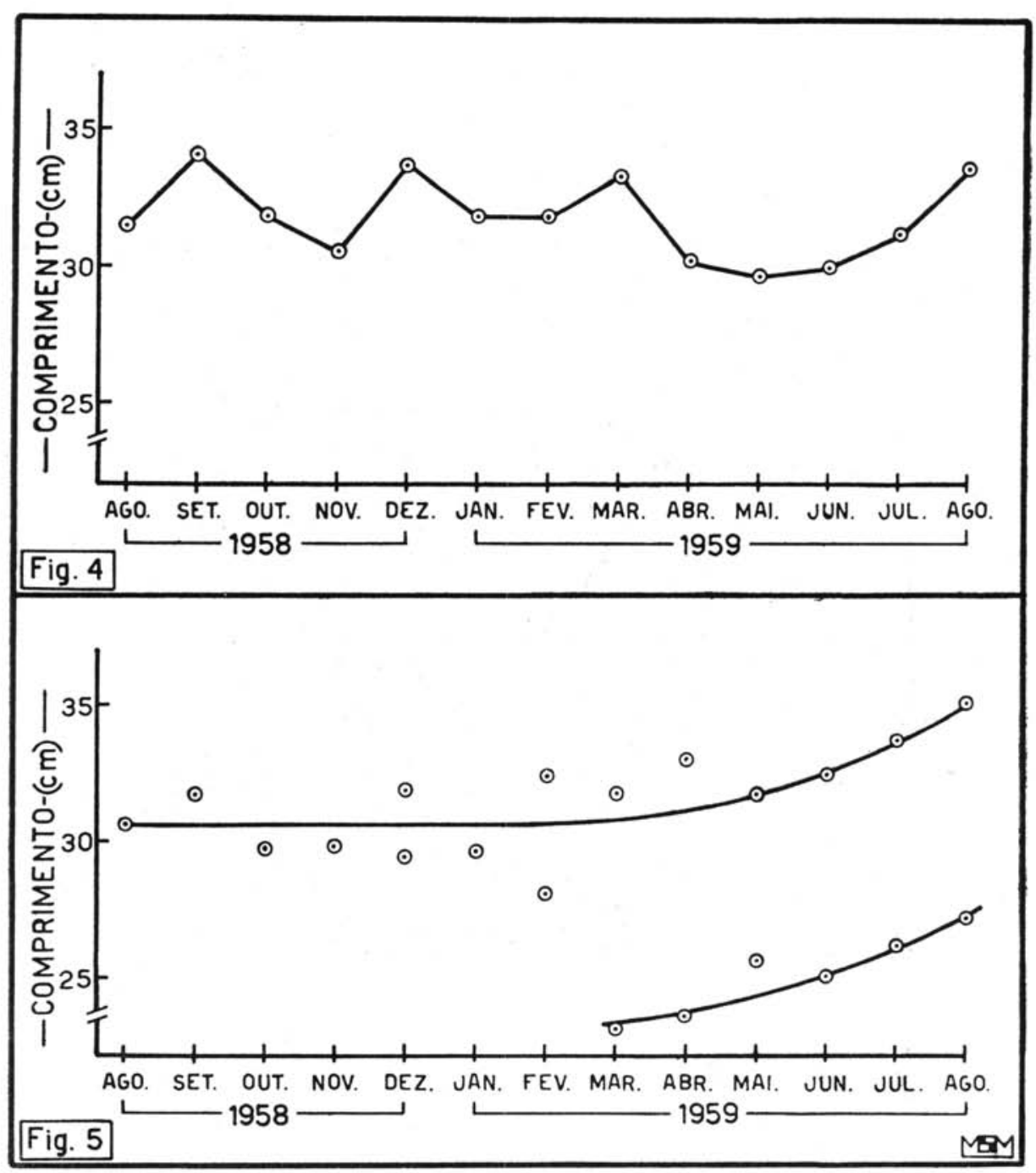

Fig. 4 - Distribuição das médias mensais de comprimento da corvina.

Fig. 5 - Principais modas mensais das distribuições mensais dos comprimentos da corvina. 


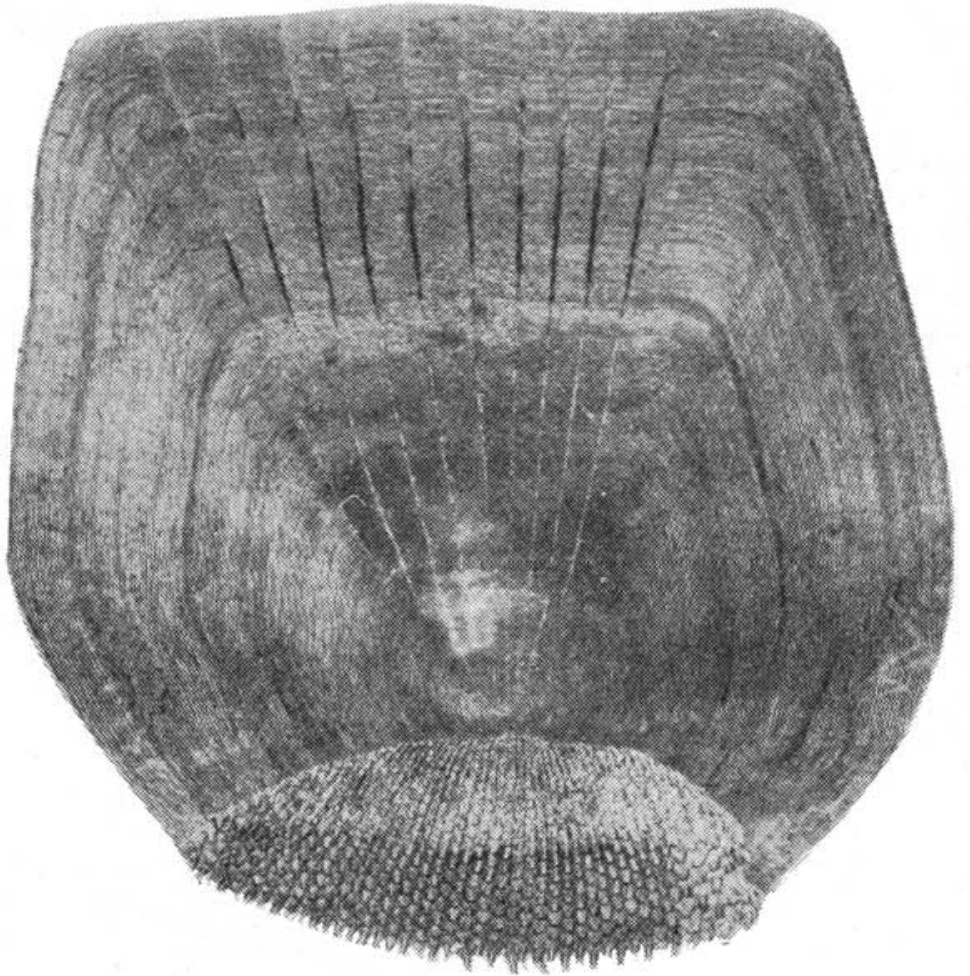

Fig. 6 - Fotografia de escama de corvina, mostrando dois anéis. 


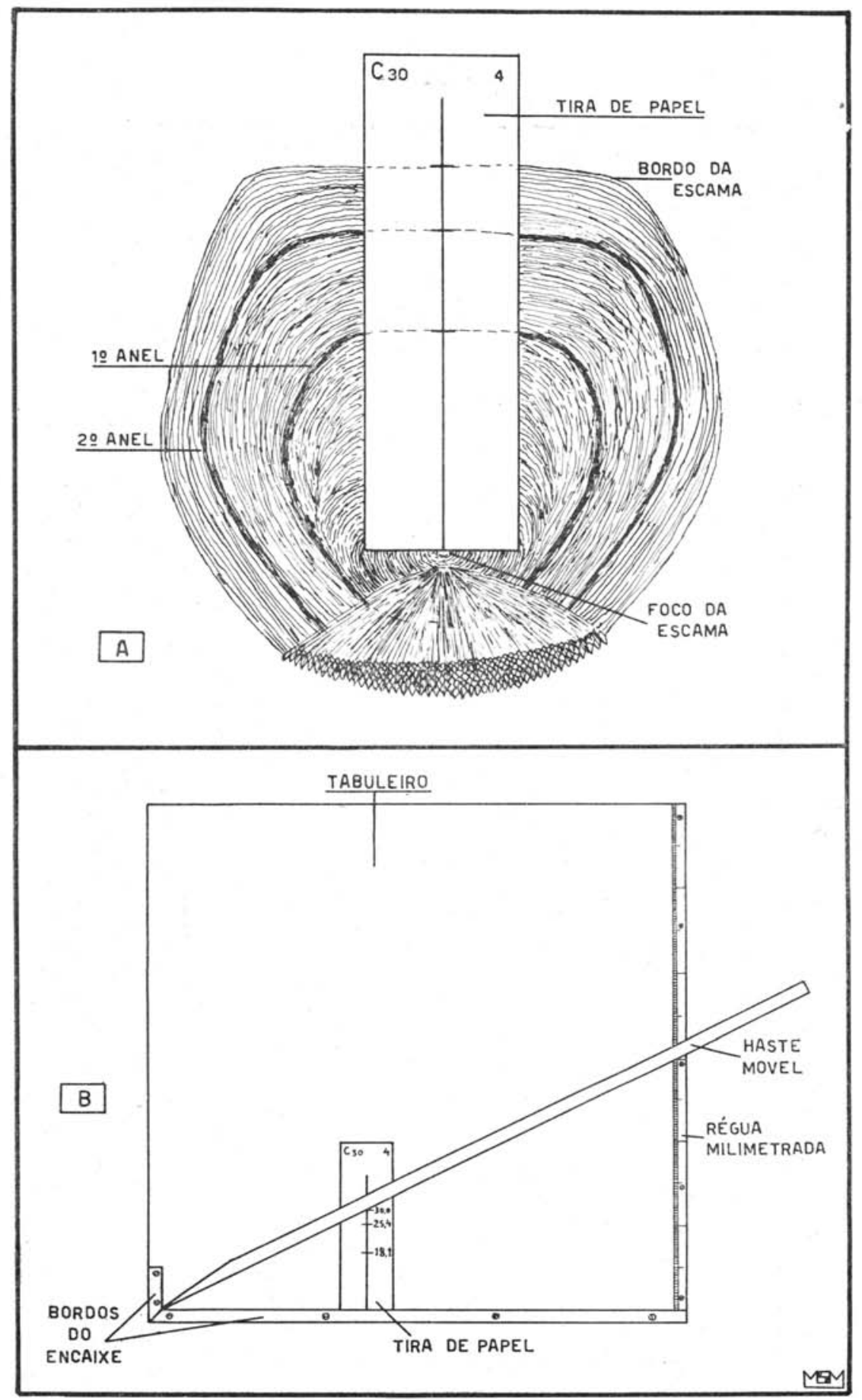

Fig. 7 - A - Projeção da escama mostrando como obter, com tira de papel, a distância relativa dos anéis em relação ao foco da escama. ' $B$ - - Tabuleiro para obtenção do comprimento do peixe, correspondente a cada anel ("retro-cálculo"). 
$-94-$

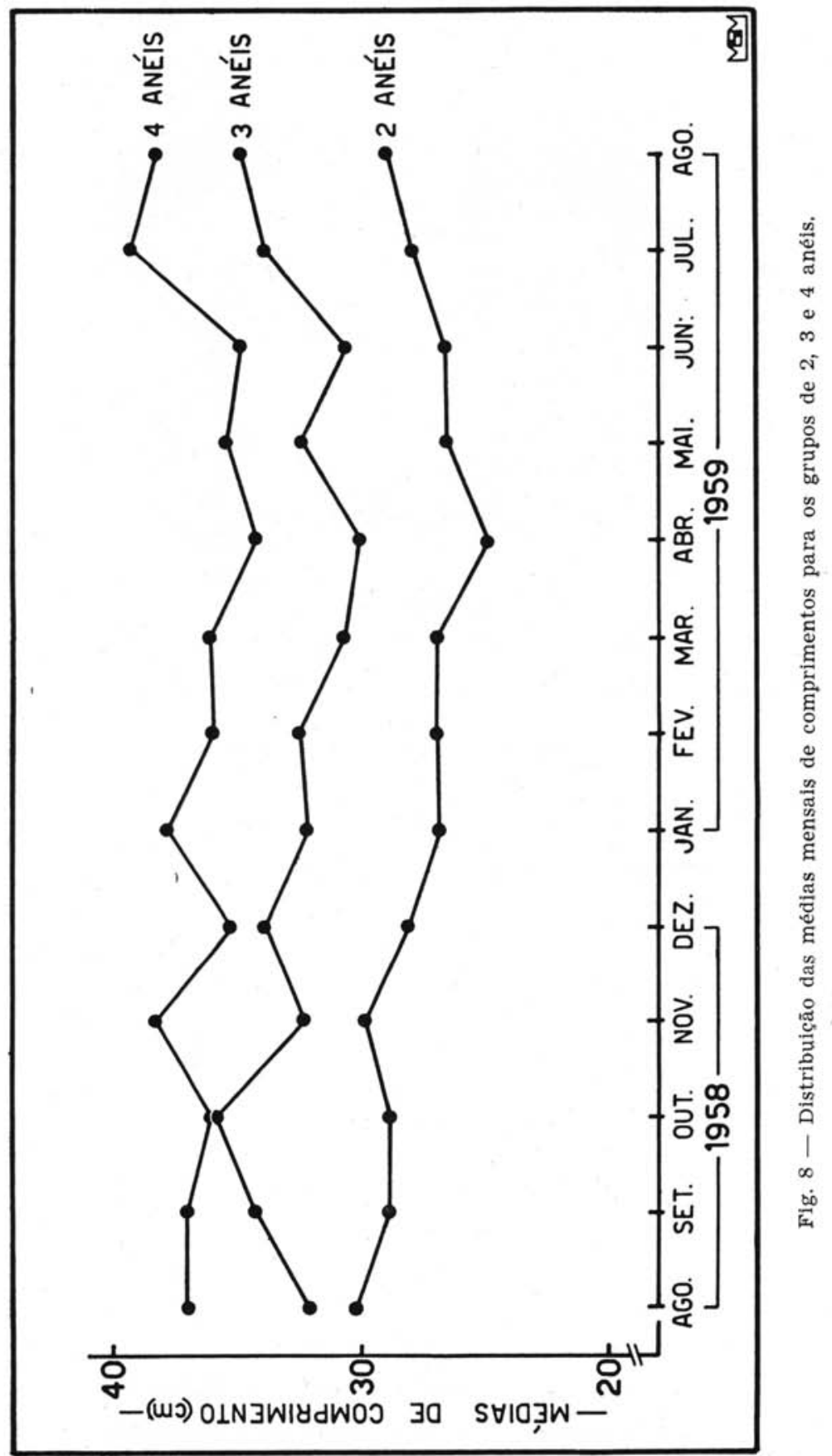




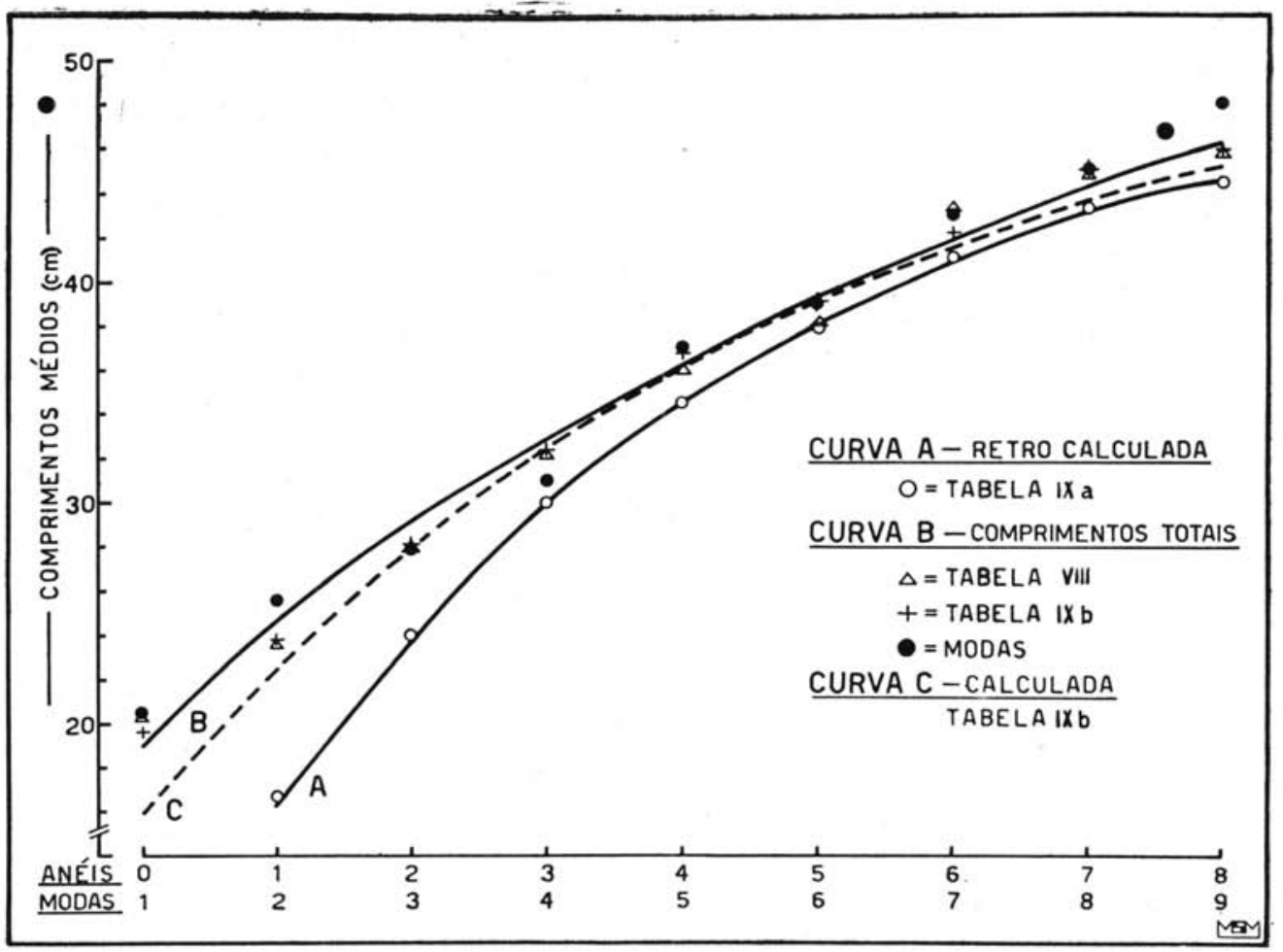

Fig. 9 - Curvas de crescimento da corvina: $A$ - Baseada nos valôres obtidos através do "retro-cálculo". $B$ - Baseada nos comprimentos totais. $C$ - Curva calculada. 


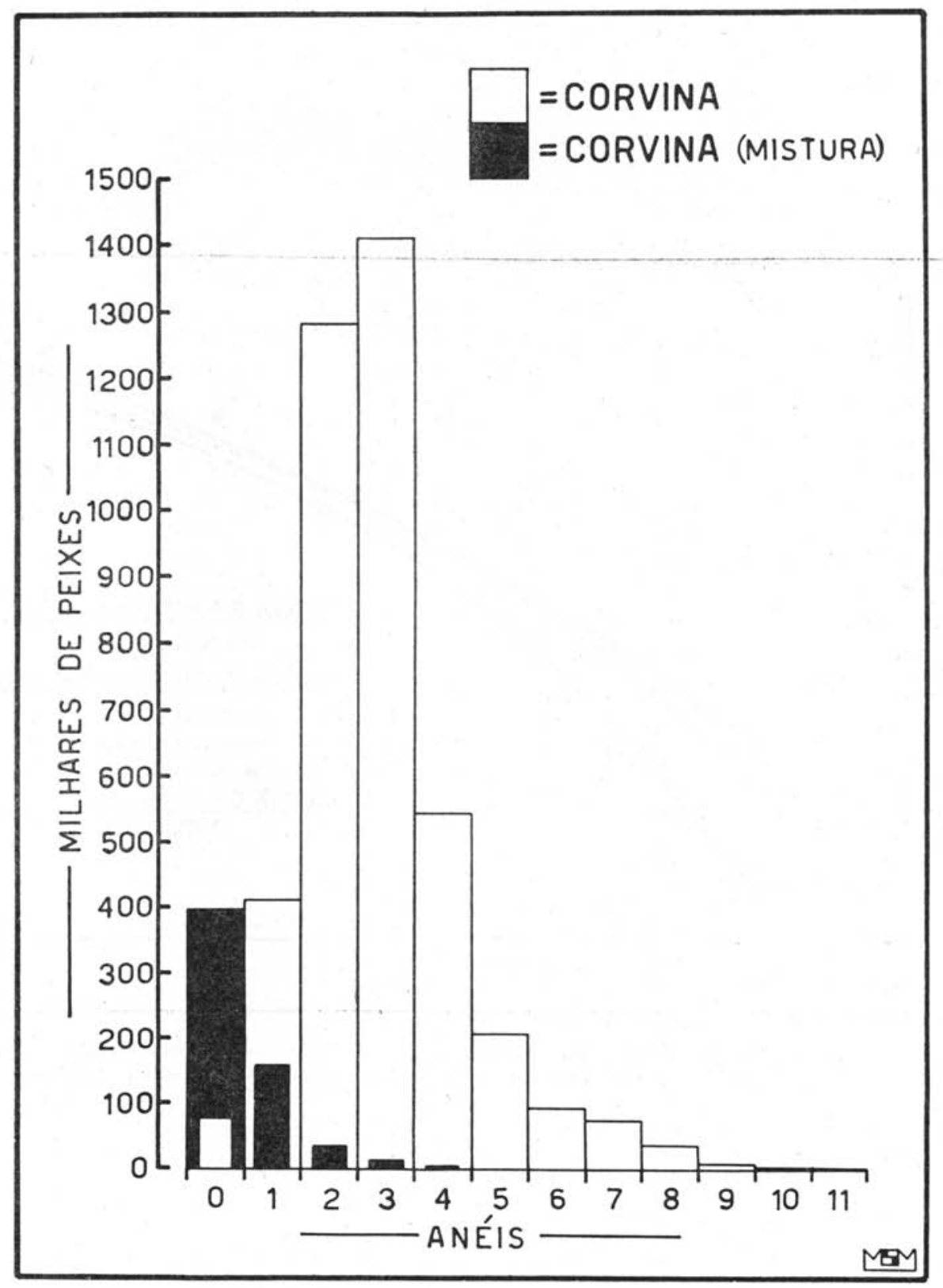

Fig. 10 - Histograma de dístribuição, em número, por grupo de anel, das corvinas e corvinas englobadas na mistura, para o periodo estudado. 


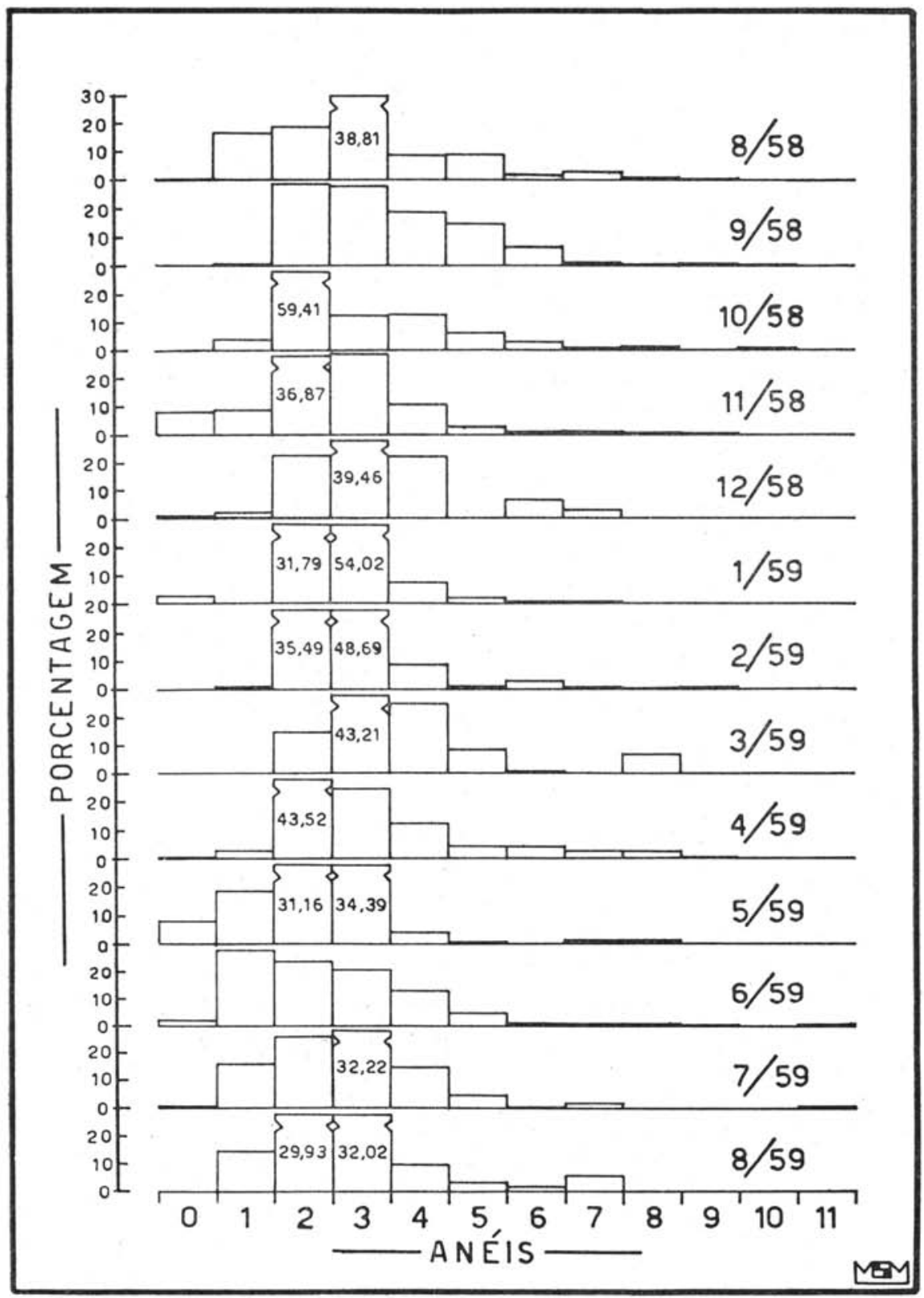

Fig. 11 - Histogramas da distribuição das freqüências mensais do total de corvinas desembarcadas, por grupo de anel. 


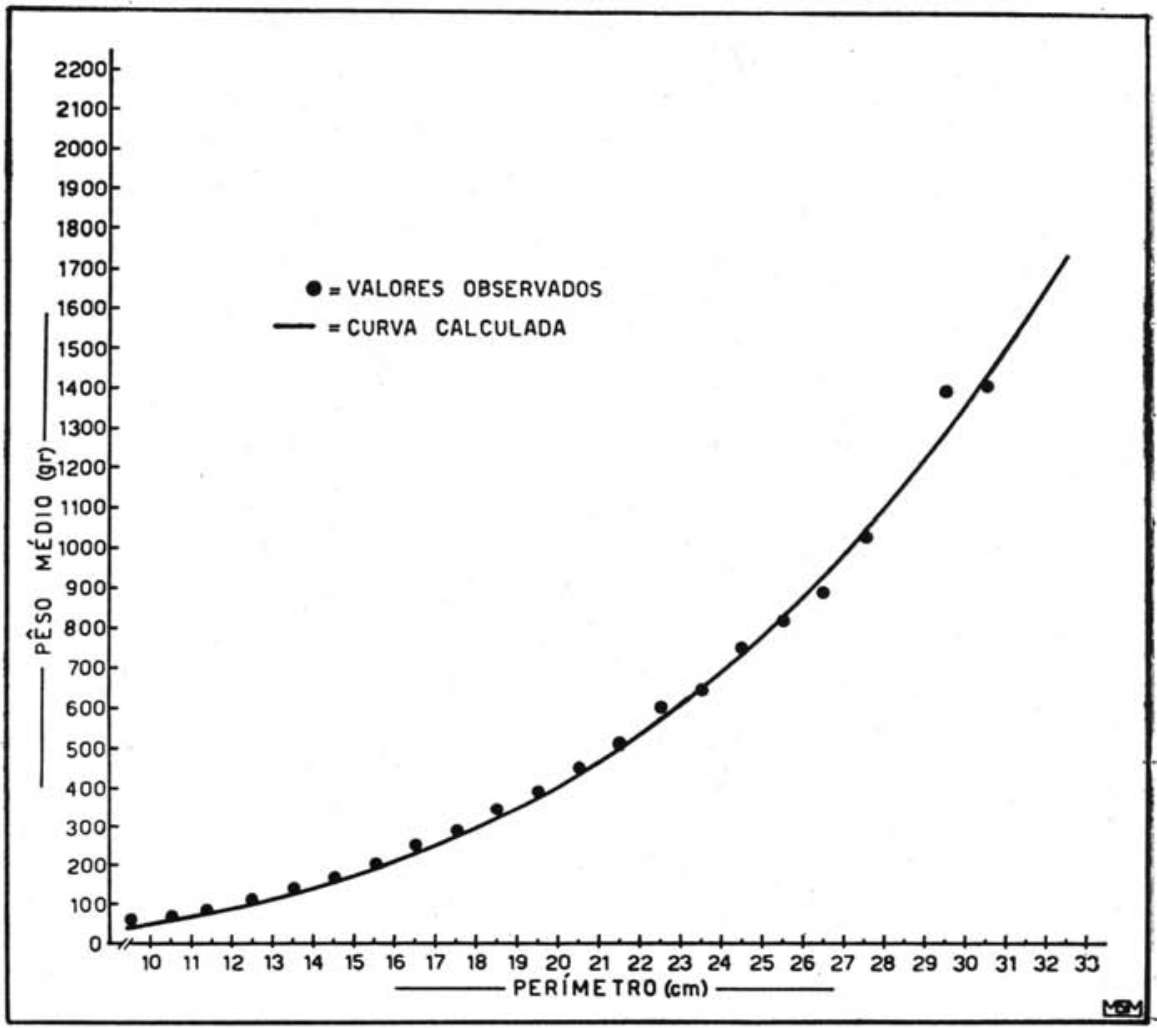

Fig. 12 - Curva representativa da relação comprimento-pêso, para a corvina, mostrando os valôres observados e a curva calculada. 


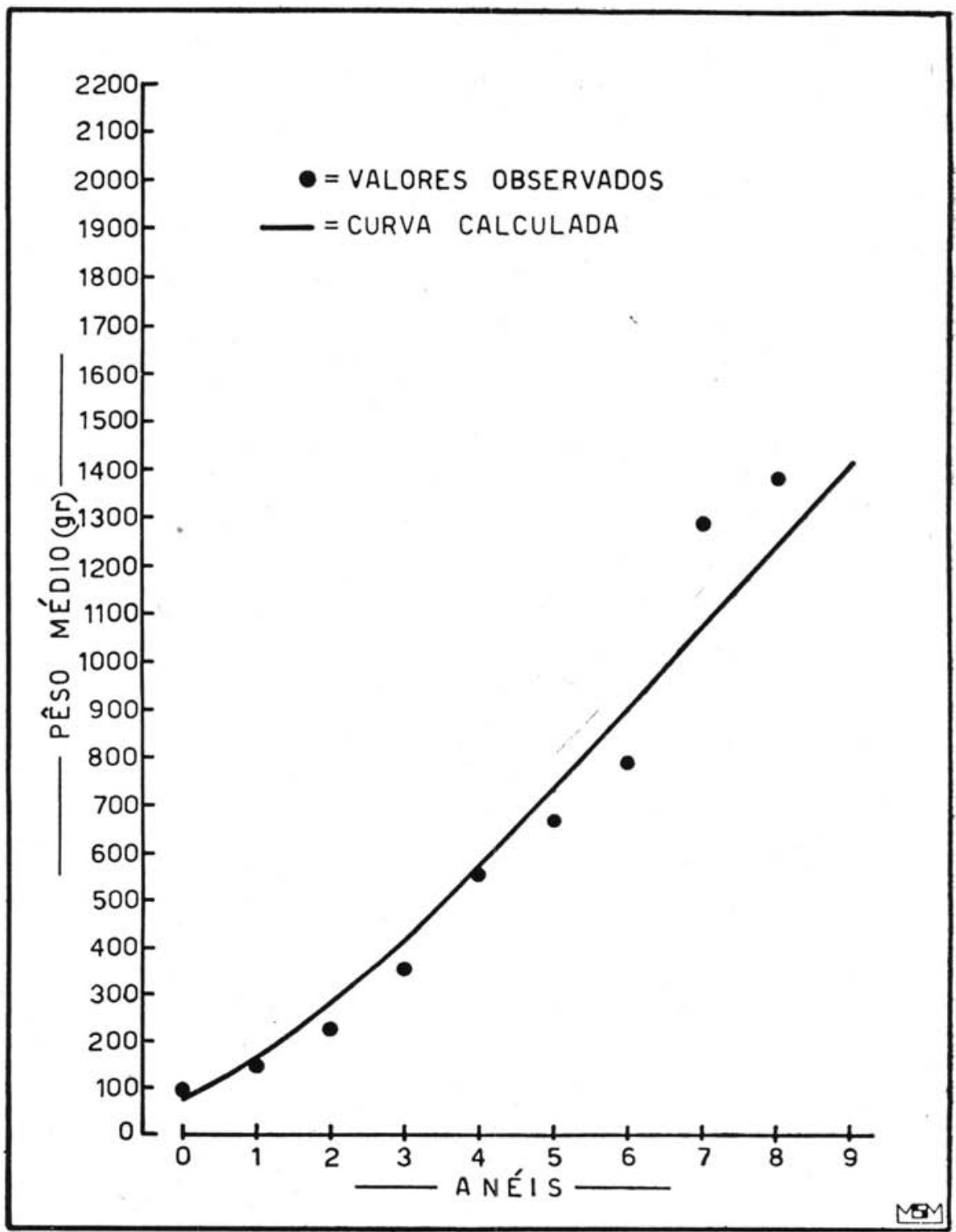

Fig. 13 - Curva de crescimento em pêso, da corvina, mostrando os vaiôres observados para cada grupo de anel e a curva calculada. 
$-100-$

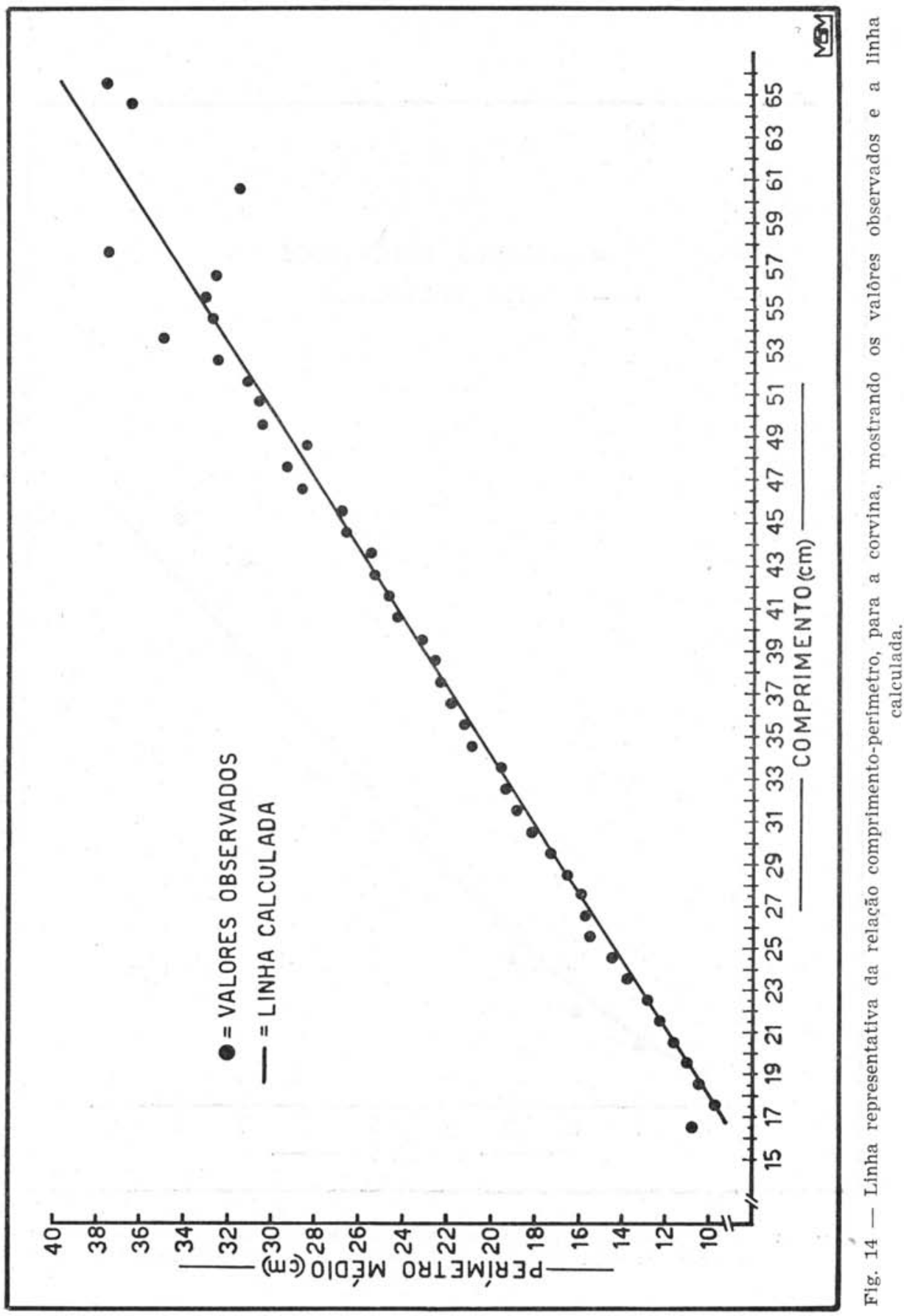




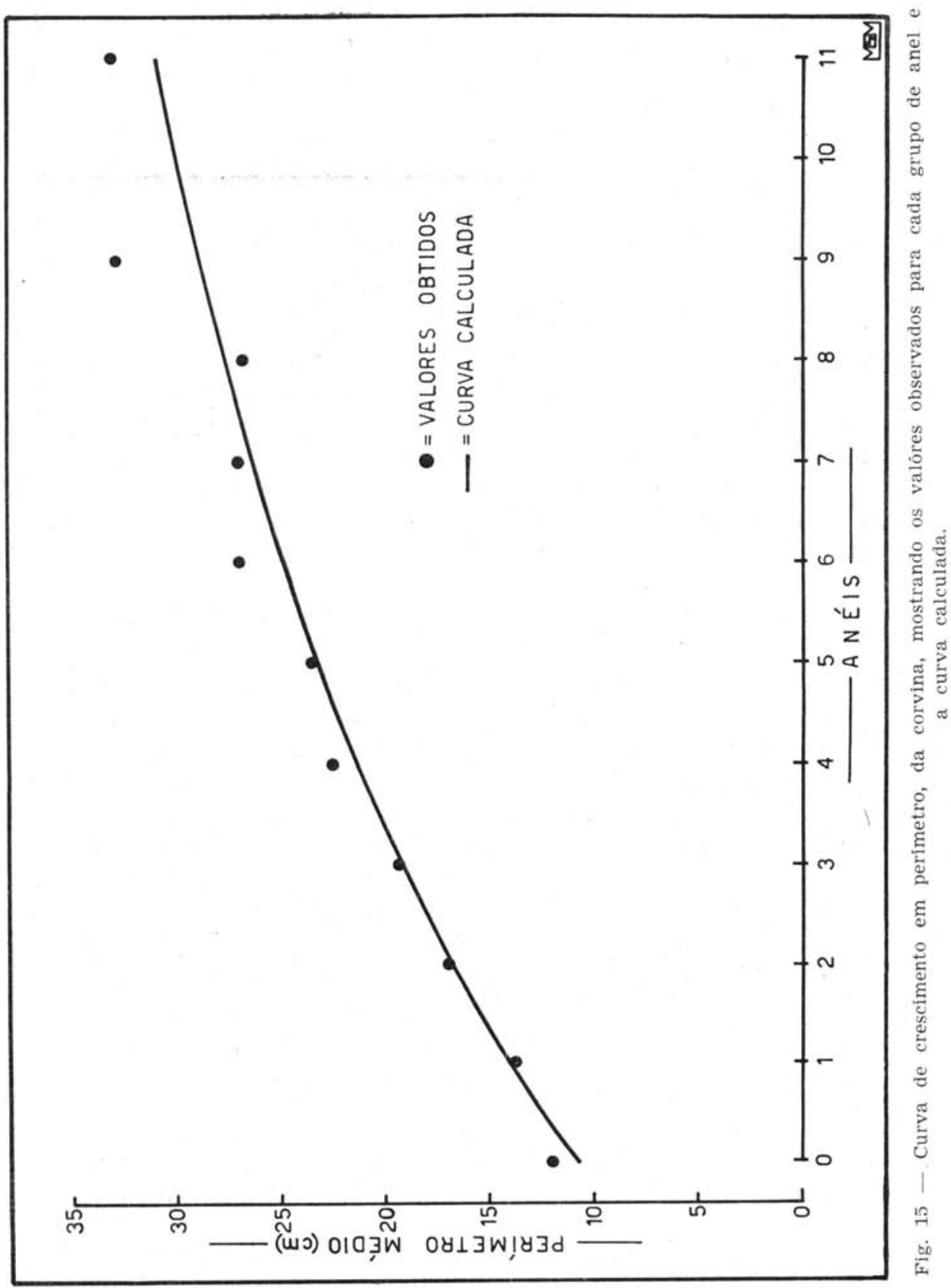




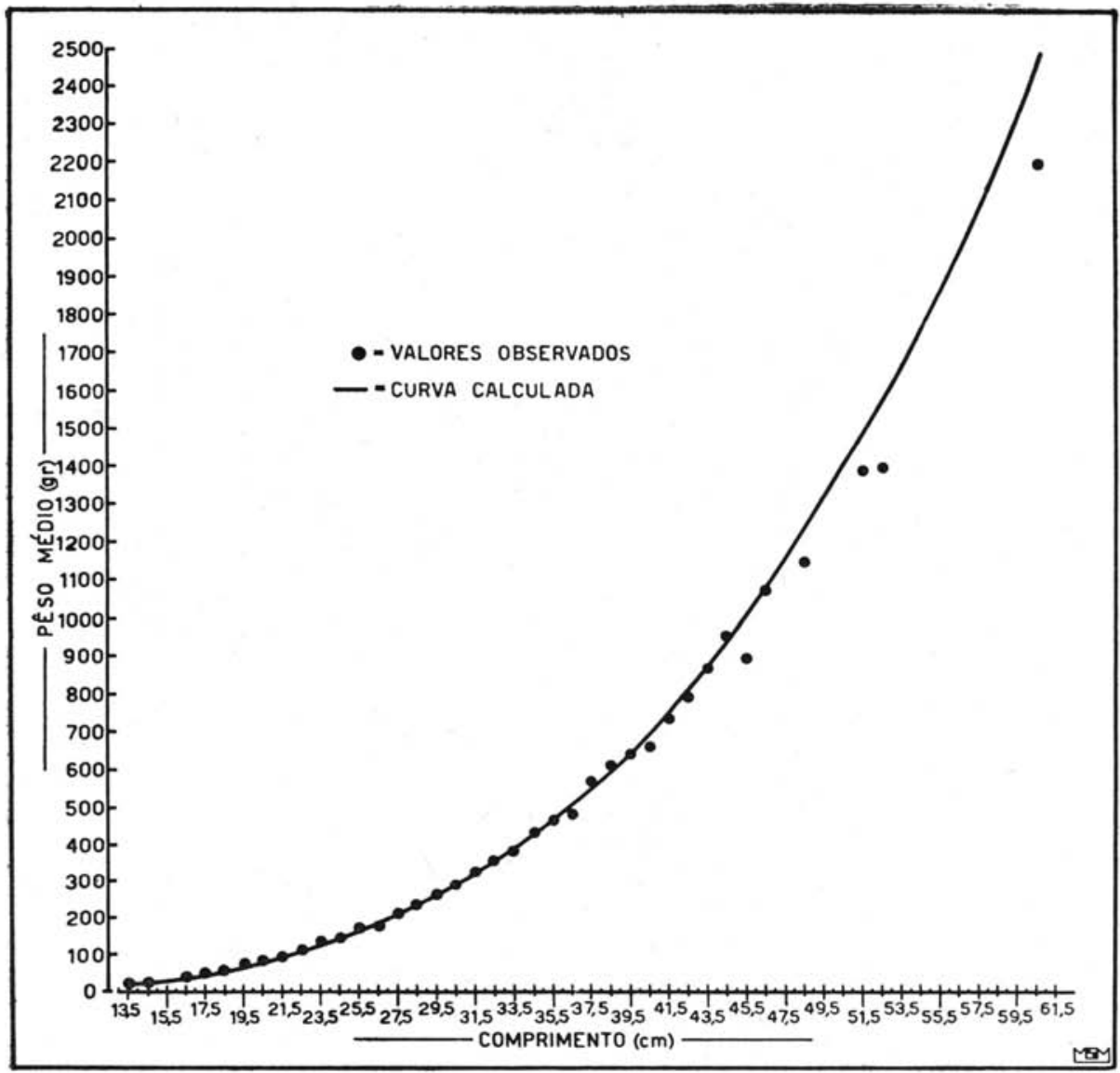

Fig. 16 - Curva representativa da relação perimetro-pêso, para a corvina, mostrando os valôres observados e a curva calculada. 